\title{
Prevention of ventilator-associated pneumonia, mortality and all intensive care unit acquired infections by topically applied antimicrobial or antiseptic agents: a meta-analysis of randomized controlled trials in intensive care units
}

\author{
Claudia Pileggi ${ }^{1 *}$, Aida Bianco ${ }^{1,2}$, Domenico Flotta ${ }^{1}$, Carmelo GA Nobile ${ }^{1}$ and Maria Pavia ${ }^{1}$
}

\begin{abstract}
Introduction: Given the high morbidity and mortality attributable to ventilator-associated pneumonia (VAP) in intensive care unit (ICU) patients, prevention plays a key role in the management of patients undergoing mechanical ventilation. One of the candidate preventive interventions is the selective decontamination of the digestive or respiratory tract (SDRD) by topical antiseptic or antimicrobial agents. We performed a meta-analysis to investigate the effect of topical digestive or respiratory tract decontamination with antiseptics or antibiotics in the prevention of VAP, of mortality and of all ICU-acquired infections in mechanically ventilated ICU patients.

Methods: A meta-analysis of randomised controlled trials was performed. The U.S. National Library of Medicine's MEDLINE database, Embase, and Cochrane Library computerized bibliographic databases, and reference lists of selected studies were used. Selection criteria for inclusion were: randomised controlled trials (RCTs); primary studies; examining the reduction of VAP and/or mortality and/or all ICU-acquired infections in ICU patients by prophylactic use of one or more of following topical treatments: 1) oropharyngeal decontamination using antiseptics or antibiotics, 2) gastrointestinal tract decontamination using antibiotics, 3) oropharyngeal plus gastrointestinal tract decontamination using antibiotics and 4) respiratory tract decontamination using antibiotics; reported enough data to estimate the odds ratio (OR) or risk ratio (RR) and their variance; English language; published through June 2010.

Results: A total of 28 articles met all inclusion criteria and were included in the meta-analysis. The overall estimate of efficacy of topical SDRD in the prevention of VAP was $27 \%$ (95\% Cl of efficacy $=16 \%$ to $37 \%$ ) for antiseptics and $36 \%(95 \% \mathrm{Cl}$ of efficacy $=18 \%$ to $50 \%)$ for antibiotics, whereas in none of the meta-analyses conducted on mortality was a significant effect found. The effect of topical SDRD in the prevention of all ICU-acquired infections was statistically significant (efficacy $=29 \% ; 95 \% \mathrm{Cl}$ of efficacy $=14 \%$ to $41 \%$ ) for antibiotics whereas the use of antiseptics did not show a significant beneficial effect.
\end{abstract}

Conclusions: Topical SDRD using antiseptics or antimicrobial agents is effective in reducing the frequency of VAP in ICU. Unlike antiseptics, the use of topical antibiotics seems to be effective also in preventing all ICU-acquired infections, while the effectiveness on mortality of these two approaches needs to be investigated in further research.

\footnotetext{
* Correspondence: claudiapileggi@unicz.it

'Department of Clinical and Experimental Medicine, Chair of Hygiene, Medical School, University of Catanzaro "Magna Græcia", via Tommaso Campanella, 88100 Catanzaro Italy

Full list of author information is available at the end of the article
} 


\section{Introduction}

Infections that develop during intensive care unit (ICU) stays represent a serious threat for critically ill patients since they affect about $30 \%$ of patients who are admitted to ICUs [1-6]. Ventilator associated pneumonia (VAP), defined as a parenchymal infection of the lung occurring in a patient who has been assisted by mechanical ventilation within the past 48 hours [7], is the most common infection acquired in the ICU [1]. VAP has a cumulative incidence of 10 to $25 \%$ and accounts for approximately $25 \%$ of all ICU infections and $50 \%$ of the antibiotics prescribed in ICU [8]. The impact of VAP is very high in terms of morbidity, complicating the course of 8 to $28 \%$ of the patients receiving mechanical ventilation $[9,10]$, prolonged ICU stays by an average of 4.3 to 6.1 days [11-13] and attributable mortality rates that range from $5.8 \%$ to $27 \%$ [12-14]. Finally, VAP imposes excess costs to health care institutions, but a precise evaluation of such over-costs is difficult because it is dependent on different factors from one country to another, such as the health care system, organization of the hospital and costs of antibiotics [15].

Several studies strongly support the hypothesis that colonization of the aerodigestive tract is primarily involved in VAP and other ICU-acquired infections' pathogenesis, since micro-organisms move into the lower respiratory tract or, through the gut, into the blood or regional lymphatics [16-22]. For these reasons selective decontamination of the aerodigestive tract represents a main objective for infection prevention in ICU patients. Moreover, the endotracheal tube plays a major role in the occurrence of VAP by providing an abnormal continuum between the upper airway and the trachea and by establishing a subglottic reservoir of secretions containing large amounts of bacterial pathogens belonging to the oropharynx and the stomach [23]. Secretions are aspirated into the trachea and then disseminated into the lungs by the ventilator [24].

Given the high morbidity and mortality attributable to VAP, prevention plays a key role in the management of patients undergoing mechanical ventilation. Therefore, a number of studies have investigated the effect of the selective decontamination of the digestive or respiratory tract by topical antiseptic or antimicrobial agents in the reduction of VAP incidence; however, current guidelines from the Center for Disease Control (CDC) for preventing health-care-associated pneumonia, released in 2003 and never updated, classify these practices as an "unresolved issue" [16]. Moreover, this topic has also been analyzed in previous meta-analyses and systematic reviews [25-31]. These reviews included trials conducted until 2006 and demonstrated the effectiveness of topical antiseptics and antibiotics in reducing VAP. However, five studies [32-36] have been most recently published on the effectiveness of antiseptics in the prevention of VAP, and four of these $[32-34,36]$ have come to opposite conclusions. Analogously, one additional trial [37] has been published on the role of topical antibiotics in the prevention of VAP that found no significant effectiveness of the treatment.

All the previously mentioned meta-analyses investigated, as a secondary outcome, the effects of topical antiseptics and antibiotics in the prevention of overall mortality, and they reported no significant effect of these interventions. Since then, five studies investigating the effect of topical antiseptics [32-36] and two of topical antibiotics [37,38] on the reduction of overall mortality have been published. Finally, several of the formerly quoted trials have investigated the role of topical antiseptics and antibiotics in the prevention of all ICU-acquired infections and have reported controversial results, whereas no meta-analyses have assessed this topic.

Therefore, we performed a meta-analysis with the following aims: our primary goal was to update metaanalyses on the effect of topical selective digestive (oropharyngeal alone or including gastrointestinal tract) or respiratory tract (subglottic area or trachea or aerosol in the respiratory loop) decontamination (SDRD) with antiseptics or antibiotics in the prevention of VAP in mechanical ventilated ICU patients; and our secondary goals were 1) to update meta-analyses on the effect of topical SDRD with antiseptics and antibiotics on mortality in mechanical ventilated ICU patients, and 2) to perform the first meta-analysis on the effect of topical SDRD with antiseptics or antibiotics on all ICU-acquired infections in mechanical ventilated ICU patients.

\section{Materials and methods \\ Search strategy}

A comprehensive systematic bibliographic search of medical literature published until June, 2010 was conducted to identify RCTs that assessed the effect of any type or combination of topical antibiotics or antiseptics on the prevention of pneumonia, all ICU-acquired infections and mortality in adults requiring mechanical ventilation in ICU.

The U.S. National Library of Medicine (MEDLINE), Embase and The Cochrane Library computerized bibliographic databases were used. In addition, we checked the references lists from all retrieved studies and meta-analyses or systematic reviews already published, to ensure that all studies could be identified. The following key words in different combinations were used: "aerosolized antibiotics", "airway colonization", "antibiotics", "antimicrobial prophylaxis", "antiseptic decontamination", "chlorhexidine", "critical care", "digestive decontamination", "healthcare-associated infections", "infection control", "intensive care units", "lower respiratory tract", 
"mechanical ventilation", "meta-analysis", "mortality", "nosocomial infection", "oropharyngeal decontamination”, "pneumonia”, "povidone-iodine”, "prevention”, "randomized controlled trials", "respiratory infection", "selective decontamination", "topical”, "ventilator-associated pneumonia".

\section{Inclusion criteria}

Articles that met the following criteria were included: (a) RCTs; (b) primary studies, not re-analyses or reviews; (c) examining the reduction of VAP and/or mortality and/or all ICU-acquired infections in mechanical ventilated ICU patients by prophylactic use of one or more of following topical treatments: 1) oropharyngeal decontamination using antiseptics or antibiotics, 2) gastrointestinal tract decontamination using antibiotics, 3) oropharyngeal plus gastrointestinal tract decontamination using antibiotics, 4) respiratory tract decontamination using antibiotics; (d) reported enough data to estimate the odds ratio (OR) or risk ratio (RR) and their variance; (e) English language; (f) published through June 2010. Trials that used systemic antibiotic prophylaxis were excluded.

\section{Assessment of study quality}

Two of the authors independently reviewed the studies included in the meta-analysis to appraise the quality of the individual trial using criteria developed for Study Protocol and Data Analysis and Presentation by Chalmers et al. [39] and the method of Jadad et al. [40]. The Chalmers et al. scale assigns a weighting factor to each item according to whether it has been addressed completely (full score), partially (half score) or not at all (no score). If an item in the protocol was not applicable, the number of possible points was reduced. The final score of each paper was calculated as the total points scored divided by the total number of points thought applicable to that study, and two sub-scores regarding quality of Study Protocol and Data Analysis and Presentation were also calculated yielding a range from 0 to a full score of 1 . The Jadad score, ranging from 0 to 5 points, was assigned to the included trials according to whether the investigators described the study as randomized and double-blind, reported the methods used to randomly assign patients and blind the intervention, and reported the number of withdrawals and dropouts and the reasons.

The readers discussed their evaluation and any disagreements were resolved through discussion and rereading.

\section{Data extraction}

The following items were collected from each clinical trial selected: a) study characteristics (authors, year of publication, design, length of follow-up); b) patients' characteristics (sample size in intervention and control groups, duration of mechanical ventilation, disease severity); c) VAP definitions and the incidence of VAP in treatment and control groups; d) all ICU-acquired infections' definitions and the incidence in treatment and control groups (we considered the number of patients who have developed at least one nosocomial infection including VAP); e) mortality in the ICU and/or in-hospital; f) type, concentration and mode of delivery of antimicrobial/antiseptics used, and control therapy.

Two independent reviewers extracted relevant trial characteristics and interobserver agreements were checked using the unweighted-kappa score [41]; differences between reviewers' data were resolved by discussion until a consensus was reached.

\section{Statistical analysis}

The pooled effects estimates were used to combine the values from the single studies and were expressed as RR and the related $95 \%$ confidence intervals (CI). RR and CI were obtained using the Mantel-Haenszel fixed effects model [42], if the studies were homogeneous, and the DerSimonian and Laird random effect model [43] in cases with heterogeneity. Statistical heterogeneity was assessed using Cochran $\mathrm{Q}$ and $\mathrm{I}^{2}$ measure; a $\mathrm{I}^{2}$ value above $25 \%$ may be considered low heterogeneity, a value above $50 \%$ and $75 \%$ were predefined as moderate and high heterogeneity $[44,45]$. We preferred applying random effects models' results in case of $\mathrm{I}^{2}$ equal or higher than $50 \%$.

\section{Sensitivity analyses}

The trials included in the meta-analysis differed considerably in several factors such as study design (method of randomization, blinding technique, modes of patients recruitment), clinical heterogeneity of patients (characteristics of participants, baseline disease severity), details of intervention (type and mode of administration of drugs, duration of treatment), and follow-up period, and subgroup analyses were used to explore eventual heterogeneity. We performed separate sensitivity analyses by grouping studies that had similar characteristics, such as patient population (medical or surgical or trauma or mixed critically ill patients); topical selective decontamination of the digestive tract or of the respiratory tract; associations of antimicrobial agents; antiseptic decontamination only with chlorhexidine; using placebo as comparator agent; double-blind studies. At last, we performed a meta-analysis to determine the potential impact of the quality of the studies on the results, by pooling only studies with Jadad scores greater than or equal to the median.

Finally, publication bias was explored by Egger's test $[46,47]$ and Begg's rank correlation test [48]. All statistical analyses were performed using Stata software, version 10 (Stata Corporation 4905 Lakeway Drive, College 
Station, Texas 77845 USA) [49]. The reporting of the study's findings was in accordance with the PRISMA statement [50].

\section{Results}

\section{Study characteristics}

A total of 333 publications were identified as potentially eligible for inclusion. Of these, 28 articles met all inclusion criteria and were included in the meta-analysis. A flow diagram providing the reasons for excluding the articles from the meta-analysis is reported in Figure 1. The agreement between the two researchers in the first comparison was $89 \%$, with a kappa score of 0.88 , and after discussion and detailed review of the articles was complete $(\mathrm{k}=1)$.

Tables 1 and 2 summarize information on the patients and design of the included trials [32-38,51-71]. All trials assessed mortality as an outcome, 25 VAP [32-34,36,37,51-63,65-71] and 13 all ICU-acquired infections $[37,38,51,52,54,56,58,60,64-68]$.

\section{Data quality}

The mean quality scores of the individual studies using the Chalmers et al. scale was extremely variable, ranging from 0.19 to 0.9 (mean $=0.64)$, for the Protocol from 0.25 to 0.97 (mean $=0.61$ ) and for the Data Analysis and Presentation from 0.13 to 0.88 (mean $=0.58$ ). It should be noted that none of the studies had a full score, both for Protocol and Data Analysis and Presentation. Almost all trials received full credit for description of daily amount and timing of therapeutic regimens (93\%), presentation of test statistic and $P$-value (93\%) and number of patients who withdrew and the reasons why $(89 \%)$, most trials reported description of relevant variables in experimental and control group (86\%), criteria for patient selection (82\%), methods for assuring masking of randomization and to evaluate success of masking (75\%) and again start and stop dates (71\%) and analysis of comparability of the study groups (61\%). A few studies reported criteria for stopping the trial (39\%), CI (36\%) and only $18 \%$ and $21 \%$ of the studies discussed

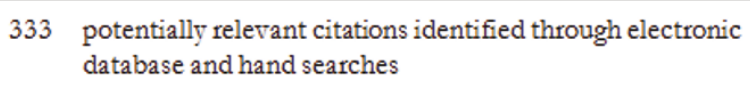

288 potentially relevant studies identified and screened on the basis of title or abstract for retrieval

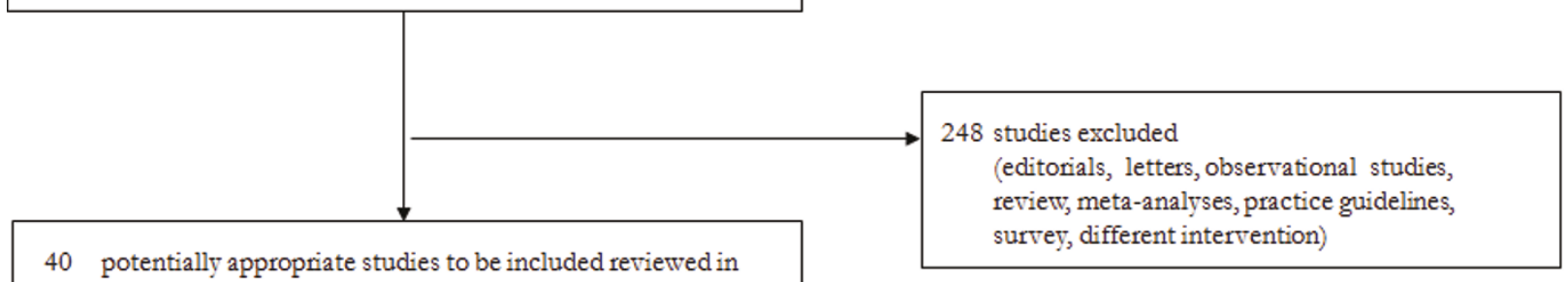

40 potentially appropriate studies to be included reviewed in detail

Figure 1 Flow chart of the published trials evaluated for inclusion in the meta-analysis. 
Table 1 Characteristics of included randomized controlled trials on topical decontamination by antiseptics

\begin{tabular}{|c|c|c|c|c|c|c|c|c|c|}
\hline Authors & Country & $\begin{array}{l}\text { Units of } \\
\text { treatment } \\
T / C^{*}\end{array}$ & Interventions & & $\begin{array}{l}\text { Delivery } \\
\text { mode }\end{array}$ & $\begin{array}{l}\text { Daily amount and } \\
\text { timing }\end{array}$ & Outcomes & $\begin{array}{l}\text { Odds Ratio; 95\% } \\
\text { Confidence Interval }\end{array}$ & Population \\
\hline & & & Treatment & Control & & & & & \\
\hline $\begin{array}{l}\text { AJ De Riso et } \\
\text { al. } 1996 \text { [51] }\end{array}$ & USA & $173 / 180$ & $\begin{array}{l}0.12 \% \mathrm{CHX}^{\dagger} \text { oral rinse }+ \\
\text { Standard oral care }\end{array}$ & $\begin{array}{l}\text { Inert solution }+ \\
\text { Standard oral care }\end{array}$ & Oropharynx $x^{\S}$ & For $30 \mathrm{~s} 2$ times/d & $\begin{array}{l}\text { VAPl In-hospital } \\
\text { mortality All ICU"- } \\
\text { acquired infections }\end{array}$ & $\begin{array}{l}0.35 ; 0.1 \text { to } 1.260 .21 \\
0.05 \text { to } 0.940 .36 ; \\
0.16 \text { to } 0.77\end{array}$ & $\begin{array}{l}\text { Cardiothoracic } \\
\text { ICU" }\end{array}$ \\
\hline $\begin{array}{l}\text { F Fourrier et al. } \\
2000^{* *}[52]\end{array}$ & France & $30 / 30$ & $0.2 \% \mathrm{CHX}^{\dagger}$ gel & Standard oral care $e^{\ddagger}$ & $\begin{array}{l}\text { Dental and } \\
\text { gingival } \\
\text { surfaces }\end{array}$ & 3 times/d & $\begin{array}{l}\text { VAP' Mortality All } \\
\text { ICU"-acquired } \\
\text { infections }\end{array}$ & $\begin{array}{l}0.36 ; 0.13 \text { to } 1.01 \\
0.43 ; 0.12 \text { to } 1.510 ; \\
2.59 \text { to } 42.21\end{array}$ & $\begin{array}{l}\text { Multidisciplinary } \\
\text { ICU" }\end{array}$ \\
\hline $\begin{array}{l}\text { S Houston et } \\
\text { al. } 2002^{++}[53]\end{array}$ & USA & $270 / 291$ & $0.12 \% \mathrm{CHX}^{\dagger}$ oral rinse & Listerine ${ }^{\ddagger \ddagger}$ oral rinse & Oropharynn $x^{\S, \S \S}$ & $\begin{array}{l}2 \text { times/d For } 10 \\
\text { days or until } \\
\text { extubation }\end{array}$ & VAPI Mortality & $\begin{array}{l}0.48 ; 0.15 \text { to } 1.54 \\
2.16 ; 0.54 \text { to } 8.53\end{array}$ & $\begin{array}{l}\text { Cardiothoracic } \\
\text { ICU" }\end{array}$ \\
\hline $\begin{array}{l}\text { F Fourrier et al. } \\
2005[54]\end{array}$ & France & $114 / 114$ & $0.2 \% \mathrm{CHX}^{\dagger}$ gel & Placebo gel & $\begin{array}{l}\text { Dental and } \\
\text { gingival } \\
\text { surfaces }\end{array}$ & $\begin{array}{l}3 \text { times/d until } 28 \\
\text { days }\end{array}$ & $\begin{array}{l}\text { VAPI ICU" mortality } \\
\text { All ICU**-acquired } \\
\text { infections }\end{array}$ & $\begin{array}{l}1.08 ; 0.52 \text { to } 2.27 \\
1.29 ; 0.81 \text { to } 2.06 \\
1.06 ; 0.51 \text { to } 2.21\end{array}$ & $\begin{array}{l}\text { Multidisciplinary } \\
\text { ICUף" }\end{array}$ \\
\hline $\begin{array}{l}\text { P Seguin et al. } \\
2006^{++}[55]\end{array}$ & France & $36 / 62$ & $\begin{array}{l}10 \% \text { povidone-iodine oral } \\
\text { rinse+ aspiration of } \\
\text { oropharyngeal secretions }\end{array}$ & $\begin{array}{l}31 \text { saline group } \| 1 \\
\text { control group }\end{array}$ & $\begin{array}{l}\text { Oropharynx } x^{\S} \\
\text { and } \\
\text { nasopharynx }\end{array}$ & Every 4 hours & VAPI ICU" mortality & $\begin{array}{l}0.21 ; 0.07 \text { to } 0.64 \\
0.65 ; 0.28 \text { to } 1.5\end{array}$ & Surgical ICU" \\
\hline $\begin{array}{l}\text { P Segers et al. } \\
2006[56]\end{array}$ & Netherland & $485 / 469$ & $\begin{array}{l}0.12 \% \mathrm{CHX}^{\dagger} \text { oral rinse and } \\
\text { nasal gel }\end{array}$ & $\begin{array}{l}\text { Placebo oral rinse } \\
\text { and nasal gel }\end{array}$ & $\begin{array}{l}\text { Oropharynx } \\
\text { and nasal } \\
\text { cavities }\end{array}$ & $\begin{array}{l}\text { Oral rinse for } 30 \mathrm{~s} \\
4 \text { times } / \mathrm{d} \text {; nasal gel } \\
4 \text { times } / \mathrm{d}\end{array}$ & $\begin{array}{l}\text { VAPl In-hospital } \\
\text { mortality All ICU"- } \\
\text { acquired infections }\end{array}$ & $\begin{array}{l}0.59 ; 0.42 \text { to } 0.831 .1 ; \\
0.39 \text { to } 3.150 .58 ; \\
0.44 \text { to } 0.78\end{array}$ & $\begin{array}{l}\text { Cardiothoracic } \\
\text { ICU" }\end{array}$ \\
\hline $\begin{array}{l}\text { M Koeman et } \\
\text { al. } 2006[57]\end{array}$ & Netherland & $127 / 130$ & $2 \% \mathrm{CHX}^{+}$in vaseline & Vaseline & Buccal cavity & 4 times/d & VAPl ICU" mortality & $\begin{array}{l}0.58 ; 0.31 \text { to } 1.09 \\
1.12 ; 0.72 \text { to } 1.17\end{array}$ & $\begin{array}{l}\text { Multidisciplinary } \\
\text { ICU }^{9}\end{array}$ \\
\hline $\begin{array}{l}\text { H Tantipong et } \\
\text { al. } 2008^{+\dagger}[32]\end{array}$ & Thailand & $102 / 105$ & $\begin{array}{l}\text { Oral care } e^{\dagger+\dagger} \text { with } 2 \% \mathrm{CHX}^{+} \\
\text {solution }\end{array}$ & $\begin{array}{l}\text { Oral care***with } \\
\text { normal saline } \\
\text { solution }\end{array}$ & Oropharynx $x^{\S}$ & 4 times/d & VAPl Mortality & $\begin{array}{l}0.58 ; 0.27 \text { to } 1.22 \\
1,0.75 \text { to } 1.34\end{array}$ & $\begin{array}{l}\text { Multidisciplinary } \\
\text { ICU General } \\
\text { medical ward }\end{array}$ \\
\hline $\begin{array}{l}\text { F Bellissimo- } \\
\text { Rodrigues et } \\
\text { al. } 2009 \text { [33] }\end{array}$ & Brazil & $98 / 96$ & $0.12 \% \mathrm{CHX}^{\dagger}$ oral rinse & Placebo oral rinse & Buccal cavity & $\begin{array}{l}3 \text { times/d until ICU } \\
\text { discharge }\end{array}$ & VAPI ICU" mortality & $\begin{array}{l}0.91 ; 0.39 \text { to } 2.06 \\
1.06 ; 0.56 \text { to } 1.99\end{array}$ & $\begin{array}{l}\text { Multidisciplinary } \\
\text { ICU" }\end{array}$ \\
\hline $\begin{array}{l}\text { TS Panchabhai } \\
\text { et al. } 2009^{+t} \\
{[34]}\end{array}$ & India & $88 / 83$ & $\begin{array}{l}\text { Cleansing }{ }^{\dagger++} \text { with } 0.2 \% \mathrm{CHX}^{\dagger} \\
+ \text { normal saline solution }\end{array}$ & $\begin{array}{l}\text { Cleansing }{ }^{\dagger+\dagger} \text { with } \\
0.01 \% \mathrm{PP}^{+\neq t}+\text { normal } \\
\text { saline solution }\end{array}$ & $\begin{array}{l}\text { Oropharynx } x^{\S} \\
\text { and } \\
\text { hypopharynx }\end{array}$ & $\begin{array}{l}2 \text { times/d until ICU } \\
\text { discharge or death }\end{array}$ & $\begin{array}{l}\text { VAPl In-hospital } \\
\text { mortality }\end{array}$ & $\begin{array}{l}0.88 ; 0.45 \text { to } 1.71 \\
1.18 ; 0.96 \text { to } 1.46\end{array}$ & $\begin{array}{l}\text { Multidisciplinary } \\
\text { ICU }\end{array}$ \\
\hline
\end{tabular}


Table 1 Characteristics of included randomized controlled trials on topical decontamination by antiseptics (Continued)

\begin{tabular}{|c|c|c|c|c|c|c|c|c|c|}
\hline $\begin{array}{l}\text { CL Munro et } \\
\text { al. } 2009^{+\dagger}[35]\end{array}$ & USA & $44 / 51$ & $0.12 \% \mathrm{CHX}^{\dagger}$ oral swab & $\begin{array}{l}\text { Oral care (not } \\
\text { specified) }\end{array}$ & Buccal cavity & 2 times/d & In-hospital mortality & $1.96 ; 0.67$ to 5.87 & $\begin{array}{l}\text { Multidisciplinary } \\
\text { ICUף }\end{array}$ \\
\hline $\begin{array}{l}\text { F Scannapieco } \\
\text { et al. } 2009 \text { [36] }\end{array}$ & USA & $116^{\S \S \S / 59}$ & $\begin{array}{l}\text { Standard oral carelll }+0.12 \% \\
\mathrm{CHX}^{+} \text {oral rinse }\end{array}$ & $\begin{array}{l}\text { Standard oral carell }{ }_{+} \\
\text {Placebo oral rinse }\end{array}$ & Buccal cavity & 2 times/d & $\begin{array}{l}\text { VAPI ICU" } \\
\text { mortality }\end{array}$ & $\begin{array}{l}0.54 ; 0.23 \text { to } 1.25 \\
1.01 ; 0.37 \text { to } 2.97\end{array}$ & Trauma ICU" \\
\hline
\end{tabular}

* Treatment/control

${ }^{\dagger}$ chlorhexidine gluconate

${ }^{\ddagger}$ mouth rinsing with bicarbonate isotonic serum followed by oropharyngeal aspiration four times a day

${ }^{\S}$ buccal, pharyngeal, gingival, tongue and tooth surfaces

ventilator associated pneumonia

" intensive care units

**single blind randomized study

${ }^{++}$not blind randomized study

\#‡ phenolic mixture

${ }^{5 \varsigma}$ patients received $15 \mathrm{ml}$ of the experimental or the control drug preoperatively

"saline solution oral rinse followed by oropharyngeal aspiration

"19 regimen without any instillation but with aspiration of oropharyngeal secretions only

*** patients received teeth brushing, oral secretions suctioning and the oropharyngeal mucosa rubbing with solution

${ }^{++t}$ oropharyngeal secretion suction and swab of the oral cavity, teeth, palate, buccal spaces, posterior pharyngeal wall and hypopharynx with normal saline solution followed by the same procedure with one of the two study solutions

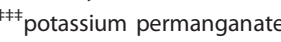

${ }^{\S \varsigma} \mathrm{s}$ two arms in treatment group: 58 patient received once daily chx and once daily placebo; 58 patients received twice daily chx

"II suction toothbrush twice a day and swabbing every four hours

१191 treatment group: 97; control group: 49 
Table 2 Characteristics of included randomized controlled trials on topical decontamination by antibiotics

\begin{tabular}{|c|c|c|c|c|c|c|c|c|c|}
\hline Authors & Country & $\begin{array}{l}\text { Units of } \\
\text { treatment } \\
T / C^{*}\end{array}$ & Interventions & & Delivery mode & $\begin{array}{l}\text { Daily } \\
\text { amount and } \\
\text { timing }\end{array}$ & Outcomes & $\begin{array}{l}\text { Odds Ratio; } \\
95 \% \\
\text { Confidence } \\
\text { Interval }\end{array}$ & Population \\
\hline & & & Treatment & Control & & & & & \\
\hline $\begin{array}{l}\text { J Klastersky } \\
\text { et al. } 1974 \\
\text { [58] }\end{array}$ & Belgium & $43 / 42$ & Gentamicin (S) & Normal saline (S) & Trachea & 3 times/d & $\begin{array}{l}\operatorname{VAP}^{\dagger} \text { Mortality All } \\
\text { ICU } \\
\text { infections }\end{array}$ & $\begin{array}{l}0.38 ; 0.17 \text { to } \\
0.861 .36 ; 0.89 \\
\text { to } 2.070 .43 ; \\
0.16 \text { to } 1.14\end{array}$ & $\begin{array}{l}\text { Neurosurgical } \\
\mathrm{ICU}^{5}\end{array}$ \\
\hline $\begin{array}{l}\text { K Unertl et } \\
\text { al! } 1987 \text { [59] }\end{array}$ & Germany & $19 / 20$ & $\begin{array}{l}\text { Polymyxin B+ } \\
\text { Gentamicin (S) } \\
\text { Amphotericin B (Su) }\end{array}$ & $\begin{array}{l}\text { No antimicrobial } \\
\text { prophylaxis }\end{array}$ & $\begin{array}{l}\text { S applied orally, nasally and } \\
\text { enterally; Su in the } \\
\text { oropharynx" (only T group) }\end{array}$ & 4 times/d & VAP $^{+}$Mortality & $\begin{array}{l}0.12 ; 0.02 \text { to } \\
0.840 .91 ; 0.43 \\
\text { to } 1.92\end{array}$ & $\begin{array}{l}\text { Multidisciplinary } \\
\text { ICU }\end{array}$ \\
\hline $\begin{array}{l}\text { C Brun } \\
\text { Buisson** et } \\
\text { al. } 1989[60]\end{array}$ & France & $36 / 50$ & $\begin{array}{l}\text { Disinfection }{ }^{++}+ \\
\text {Polymyxin E+ } \\
\text { Neomycin }+ \text { Nalidixic } \\
\text { acid (S) }\end{array}$ & Disinfection $^{\dagger+}$ & $\begin{array}{l}\text { Disinfection }{ }^{+\dagger} \text { of oropharynx"; } \\
\text { S applied orally and enterally }\end{array}$ & $\begin{array}{l}\text { Disinfection }{ }^{\text {t† }} \\
3 \text { times/d; S } 4 \\
\text { times/d }\end{array}$ & $\begin{array}{l}V P^{\dagger} I C U^{\S} \\
\text { mortality All ICU } \\
\text { acquired infections }\end{array}$ & $\begin{array}{l}0.69 ; 0.19 \text { to } \\
2.590 .94 ; 0.51 \\
\text { to } 1.730 .97 \\
0.35 \text { to } 2.63\end{array}$ & Medical ICU \\
\hline $\begin{array}{l}\text { JM } \\
\text { Rodriguez- } \\
\text { Roldan et al. } \\
1990[61)\end{array}$ & Spain & $13 / 15$ & $\begin{array}{l}\text { Disinfection }{ }^{\neq \neq}+ \\
\text {Polymyxin E+ } \\
\text { Tobramycin or } \\
\text { Netilmicin+ } \\
\text { Amphotericin B (P) }\end{array}$ & $\begin{array}{l}\text { Disinfection }{ }^{\neq \neq}+\text {Inert } \\
\text { coloring substance }(P)\end{array}$ & Oropharynx" & 4 times/d & $\begin{array}{l}\operatorname{VAP}^{\dagger} \text { In-hospital } \\
\text { mortality }\end{array}$ & $\begin{array}{l}0.05 ; 0.0 \text { to } 0.77 \\
0.92 ; 0.31 \text { to } \\
2.73\end{array}$ & $\begin{array}{l}\text { Multidisciplinary } \\
I^{\prime C U^{\S}}\end{array}$ \\
\hline $\begin{array}{l}\text { J Pugin et al. } \\
1991[62]\end{array}$ & Switzerland & $25 / 27$ & $\begin{array}{l}\text { Polymyxin B+ } \\
\text { Neomycin+ } \\
\text { Vancomycin (S) }\end{array}$ & Dextrose $5 \%(\mathrm{~S})$ & $\begin{array}{l}\text { Unconscious patients: instilled } \\
\text { into retropharynx. Conscious } \\
\text { patients: keep the solution in } \\
\text { buccal cavity for } 1 \text { minute and } \\
\text { then to shallow it }\end{array}$ & Every $24 \mathrm{~h}$ & $\begin{array}{l}\operatorname{VAP}^{\dagger} \text { In-hospital } \\
\text { mortality }\end{array}$ & $\begin{array}{l}0.21 ; 0.08 \text { to } \\
0.521 .08 ; 0.44 \\
\text { to } 2.64\end{array}$ & Surgical ICU \\
\hline $\begin{array}{l}\text { H Gastinne } \\
\text { et al. } 1992 \\
\text { [63] }\end{array}$ & France & $220 / 225$ & $\begin{array}{l}\text { Colistin+ Tobramycin } \\
+ \text { Amphotericin B (S, } \\
\text { G) }\end{array}$ & $\begin{array}{l}\text { Nonabsorbable calcium } \\
\text { salt }(S, G)\end{array}$ & G in oropharynx"; S enterally & 4 times/d & $\begin{array}{l}\operatorname{VAP}^{+} \text {In-hospital } \\
\text { mortality }\end{array}$ & $\begin{array}{l}1.3 ; 0.8 \text { to } 2.1 \\
1.08 ; 0.89 \text { to } 1.3\end{array}$ & Medical ICU \\
\hline $\begin{array}{l}\text { FB Cerra et } \\
\text { al. } 1992[64]\end{array}$ & USA & $25 / 21$ & $\begin{array}{l}\text { Norfloxacin (Su) + } \\
\text { Nystatin (Su) }\end{array}$ & Cherry syrup (Su) & Enterally & $\begin{array}{l}\text { Norfloxacin } \times \\
3 \text { Nystatin } \times 4 \\
\text { limited to } 15 \\
\text { d }\end{array}$ & $\begin{array}{l}I C U^{\S} \text { mortality All } \\
I C U^{\S} \text {-acquired } \\
\text { infections }\end{array}$ & $\begin{array}{l}1.08 ; 0.64 \text { to } \\
1.840 .67 ; 0.41 \\
\text { to } 1.1\end{array}$ & Surgical ICU \\
\hline $\begin{array}{l}\text { AM Korinek } \\
\text { et al. } 1993 \\
{[65]}\end{array}$ & France & $63 / 60$ & $\begin{array}{l}\text { Polymyxin E+ } \\
\text { Tobramycin+ } \\
\text { Amphotericin B (S) } \\
\text { and P containing } \\
\text { same antibiotics plus } \\
\text { Vancomycin }\end{array}$ & $\begin{array}{l}\text { Sterile water (S) } \\
\text { Carboxymethylcellulose } \\
(\mathrm{P})\end{array}$ & $\begin{array}{l}P \text { in oropharynx } \mathrm{S} \\
\text { administered enterally }\end{array}$ & $\begin{array}{l}4 \text { times } / d \\
\text { limited to } 15 d\end{array}$ & $\begin{array}{l}\text { VAP }^{\dagger} I C U^{\S} \\
\text { mortality In- } \\
\text { hospital mortality } \\
\text { All ICU } \\
\text { infections }\end{array}$ & $\begin{array}{l}0.57 ; 0.34 \text { to } \\
0.970 .57 ; 0.22 \\
\text { to } 1.481 .09 ; \\
0.59 \text { to } 2.01 \\
0.56 ; 0.42 \text { to } \\
0.76\end{array}$ & $\begin{array}{l}\text { Neurosurgical } \\
I C U^{\S}\end{array}$ \\
\hline $\begin{array}{l}\text { J Wiener et } \\
\text { al. } 1995 \text { [66] }\end{array}$ & USA & $30 / 31$ & $\begin{array}{l}\text { Polymyxin E+ } \\
\text { Gentamicin+ Nystatin } \\
(\mathrm{S}, \mathrm{P})\end{array}$ & Inert $S$ and $P$ & $\begin{array}{l}\mathrm{P} \text { in oropharynx } \mathrm{S} \\
\text { administered enterally }\end{array}$ & 4 times/d & $\begin{array}{l}V P^{\dagger} I C U^{\S} \\
\text { mortality All ICU } \\
\text { acquired infections }\end{array}$ & $\begin{array}{l}1.03 ; 0.45 \text { to } 2.4 \\
0.78 ; 0.45 \text { to } \\
1.340 .82 ; 0.27 \\
\text { to } 2.53\end{array}$ & $\begin{array}{l}\text { Multidisciplinary } \\
\mathrm{ICU}^{\S}\end{array}$ \\
\hline $\begin{array}{l}\text { B Quinio et } \\
\text { al. } 1996[67]\end{array}$ & France & $76 / 72$ & $\begin{array}{l}\text { Polymyxin E+ } \\
\text { Gentamicin+ } \\
\text { Amphotericin B (Su, } \\
\text { P) })^{\S \S}\end{array}$ & $\begin{array}{l}\text { Carboxymethylcelloulose } \\
(\text { Su, P })^{\$ S}\end{array}$ & $\begin{array}{l}\text { G in oropharynx" S } \\
\text { administered enterally }\end{array}$ & 4 times/d & $\begin{array}{l}V^{V A P^{+}} I C U^{\S} \text { mortality } \\
\text { All ICU } \\
\text { infections }\end{array}$ & $\begin{array}{l}0.49 ; 0.31 \text { to } \\
0.761 .12 ; 0.75 \\
\text { to } 1.670 .6 ; 0.49 \\
\text { to } 0.75\end{array}$ & $\begin{array}{l}\text { Multiple trauma } \\
\text { patients } \\
\text { admitted in } \\
I_{C} U^{\S}\end{array}$ \\
\hline
\end{tabular}


Table 2 Characteristics of included randomized controlled trials on topical decontamination by antibiotics (Continued)

\begin{tabular}{|c|c|c|c|c|c|c|c|c|c|}
\hline $\begin{array}{l}\text { DCJJ } \\
\text { Bergmans et } \\
\text { al. } 2001 \text { [68] }\end{array}$ & Netherland & $87 / 139$ & $\begin{array}{l}\text { Polymyxin E+ } \\
\text { Gentamicin+ } \\
\text { Vancomycin (O) }\end{array}$ & O without antibiotics" & Buccal cavity & $\begin{array}{l}\text { Every } 6 \mathrm{~h} \\
\text { limited to } 21 \mathrm{~d}\end{array}$ & $\begin{array}{l}V^{V A P^{\dagger}} I C U^{\S} \\
\text { mortality In- } \\
\text { hospital mortality } \\
\text { All ICU-acquired } \\
\text { infections }\end{array}$ & $\begin{array}{l}0.37 ; 0.19 \text { to } \\
0.740 .65 ; 0.35 \\
\text { to } 1.210 .71 ; \\
0.39 \text { to } 1.29 \\
0.61 ; 0.34 \text { to } 1.1\end{array}$ & $\begin{array}{l}\text { Multidisciplinary } \\
\mathrm{ICU}^{\S}\end{array}$ \\
\hline $\begin{array}{l}\text { GC Wood et } \\
\text { al. } 2002[69]\end{array}$ & USA & $20 / 20$ & Ceftazidime (A) & Normal saline (A) & $\begin{array}{l}\text { Nebulizer connected to the } \\
\text { inspiratory loop }\end{array}$ & $\begin{array}{l}\text { Every } 12 \\
\text { hours for } \geq \\
7 d\end{array}$ & $\operatorname{VAP}^{\dagger}$ Mortality & $\begin{array}{l}0.47 ; 0.23 \text { to } \\
0.980 .41 ; 0.06 \\
\text { to } 2.41\end{array}$ & Trauma ICU \\
\hline $\begin{array}{l}\text { I } \\
\text { Pneumatikos } \\
\text { et al. 2002** } \\
\text { [70] }\end{array}$ & Greece & $31 / 30$ & $\begin{array}{l}\text { Polymyxin E+ } \\
\text { Tobramycin+ } \\
\text { Amphotericin B (S) }\end{array}$ & Placebo S & Subglottic area & $\begin{array}{l}\text { Continuous } \\
\text { infusion }\end{array}$ & VAP $^{\dagger}$ Mortality & $\begin{array}{l}0.37 ; 0.17 \text { to } \\
0.810 .63 ; 0.14 \\
\text { to } 2.7\end{array}$ & $\begin{array}{l}\text { Multiple trauma } \\
\text { patients } \\
\text { admitted in } \\
I C U^{\S}\end{array}$ \\
\hline $\begin{array}{l}\text { M Koeman et } \\
\text { al. } 2006[57]\end{array}$ & Netherland & $128 / 130$ & $\begin{array}{l}\mathrm{CHX} \mathrm{X}^{\mathrm{II}}+\text { Colistin in } \\
\text { vaseline }\end{array}$ & Vaseline & Buccal cavity & 4 times/d & $\begin{array}{l}\text { VAPt ICU } \\
\text { mortality }\end{array}$ & $\begin{array}{l}0.82 ; 0.41 \text { to } \\
1.631 .02 ; 0.66 \\
\text { to } 1.59\end{array}$ & $\begin{array}{l}\text { Multidisciplinary } \\
\mathrm{ICU}^{\S}\end{array}$ \\
\hline $\begin{array}{l}\text { M Kollef et } \\
\text { al. } 2006 \text { [71] }\end{array}$ & $\begin{array}{l}\text { Multinational } \\
\text { study }\end{array}$ & $362 / 347$ & Iseganan (S) & Placebo S & Oropharynx" & $\begin{array}{l}\text { For } 2 \text { min } 6 \\
\text { times/d } \\
\text { limited to } 14 d\end{array}$ & $\begin{array}{l}\operatorname{VAP}^{\dagger} I C U^{\S} \\
\text { mortality at } 14 d\end{array}$ & $\begin{array}{l}0.86 ; 0.68 \text { to } \\
1.091 .28 ; 0.87 \\
\text { to } 1.88\end{array}$ & $\begin{array}{l}\text { Multidisciplinary } \\
\text { ICU }^{\S}\end{array}$ \\
\hline $\begin{array}{l}\text { JA Claridge } \\
\text { et al. } 2007 \\
{[37]}\end{array}$ & USA & $53 / 52$ & Ceftazidime (A) & Normal saline(A) & $\begin{array}{l}\text { Nebulizer connected to the } \\
\text { inspiratory loop }\end{array}$ & $\begin{array}{l}\text { Every } 12 \\
\text { hours for } \geq \\
7 d\end{array}$ & $\begin{array}{l}\text { VAP }{ }^{\dagger} \text { Mortality All } \\
\text { ICU }^{\S} \text {-acquired } \\
\text { infections }\end{array}$ & $\begin{array}{l}0.98 ; 0.67 \text { to } \\
1.431 .08 ; 0.63 \\
\text { to } 1.851 .71 ; \\
0.67 \text { to } 4.48\end{array}$ & Trauma ICU \\
\hline $\begin{array}{l}\text { AM de Smet } \\
\text { et al. 2009** } \\
\text { [38] }\end{array}$ & Netherland & 1904/1990 & $\begin{array}{l}\text { Polymyxin } \mathrm{E}+ \\
\text { Amphotericin B+ } \\
\text { Tobramycin (P) }\end{array}$ & Standard oral care & Buccal cavity (only T group) & 4 times/d & $\begin{array}{l}\text { In-hospital } \\
\text { mortality ICU } \\
\text { mortality Mortality } \\
\text { at day } 28 \text { All ICU } \\
\text { acquired } \\
\text { infections }\end{array}$ & $\begin{array}{l}0.95 ; 0.83 \text { to } \\
1.090 .98 ; 0.84 \\
\text { to } 1.150 .96 ; \\
0.74 \text { to } 0.99 \\
0.68 ; 0.53 \text { to } \\
0.86\end{array}$ & $\begin{array}{l}\text { Multidisciplinary } \\
\mathrm{ICU}^{\S}\end{array}$ \\
\hline
\end{tabular}

* treatment/control, ${ }^{+}$ventilator associated pneumonia, ${ }^{5}$ intensive care units, I randomized study blinded for radiologic diagnosis, ${ }^{\mathbb{9}}$ buccal, pharyngeal, gingival, tongue and tooth surfaces, ${ }^{* *}$ not blind randomized study, ${ }^{+\dagger}$ disinfection with a povidone-iodine solution, ${ }^{\neq \dagger}$ disinfection with a $0.1 \%$ chlorhexidine solution, ${ }^{\S \S}$ both groups received nasal and oropharyngeal toilet with povidone-iodine before each treatment or placebo application, "two separate control groups: control a (78) was studied in the presence of patients receiving topical antimicrobial prophylaxis; control b (61) was studied in ICU where no topical antimicrobial prophylaxis was used

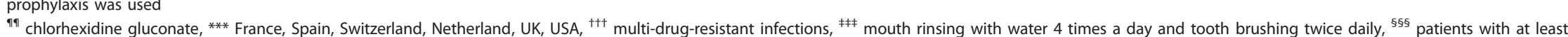
one episode of bacteremia or candidemia acquired in ICU. 
beta error and side effects of treatment, respectively (Table 3). With regard to the Jadad et al. criteria, the mean score was 3.39 (median 4), most trials addressed adequately the problems of withdrawals or dropouts after randomization (74\%) and were classified as doubleblinded (63\%). Only eight trials [33,36,56,57,64,66,68,71] had a full score on the Jadad et al. scale. It should be noted that there has been improvement in study design and reporting, since findings published more recently tended to receive a higher quality rating.

\section{Meta-analysis}

Results of the meta-analyses that explored the effects of topical use of antiseptics and antibiotics on the prevention of VAP, mortality and all ICU-acquired infections are shown in Table 4.

\section{VAP}

The incidence reduction of VAP in ICU patients by topical SDRD was the main outcome measured. Results from 11 trials [32-34,36,51-57] were available for the analysis of the effects of topical digestive decontamination with antiseptics (Figure 2). The overall estimate of efficacy of antiseptics in the fixed effects model was $27 \%$ $(95 \% \mathrm{CI}$ of efficacy $=16 \%$ to $37 \%)$ and the $\mathrm{I}^{2}$ statistic test of homogeneity found a low heterogeneity across the various studies $\left(\mathrm{Q}=13.78 P=0.18 ; \mathrm{I}^{2}=27.4 \%\right)$. Meta-analysis of the 15 trials that tested the effect of topical SDRD by antibiotics [37,57-63,65-71] (Figure 2) found a similar (36\%) statistically significant reduction in VAP rates $(95 \% \mathrm{CI}$ of efficacy $=18 \%$ to $50 \%)$ but the test of homogeneity showed a moderate degree of statistically significant heterogeneity $\left(\mathrm{Q}=47.09 \mathrm{P}<0.001 ; \mathrm{I}^{2}\right.$ $=70.3 \%$ ).

The results of the meta-analyses after limiting the analysis to high or low quality studies were not substantially changed, although the efficacy was higher in the low quality studies that used antiseptics and antibiotics as

Table 3 Distribution of studies by quality scoring values according to the Chalmers et al. method

\begin{tabular}{|c|c|c|}
\hline \multirow{2}{*}{$\begin{array}{l}\text { Quality items } \\
\text { Research protocol }\end{array}$} & \multicolumn{2}{|c|}{ Adequate } \\
\hline & N. & $\%$ \\
\hline Description of inclusion and rejection criteria for patient selection (28) & 23 & 82 \\
\hline Number and description of patients eligible not accepted (28) & 16 & 57 \\
\hline Daily amount and timing of therapeutic regimen (28) & 26 & 93 \\
\hline Physical appearance of placebo/control similar to the treatment (21) & 16 & 76 \\
\hline Taste of placebo/control similar to the treatment (21) & 10 & 48 \\
\hline Description and appropriate use of methods for assuring masking of randomization (28) & 21 & 75 \\
\hline Patients masked treatment (27) & 18 & 67 \\
\hline Observers masked to treatment (27) & 17 & 63 \\
\hline Observers masked to results (28) & 6 & 21 \\
\hline Prior estimate of sample size and power calculation (28) & 15 & 54 \\
\hline Definition of criteria for stopping the trial (28) & 11 & 39 \\
\hline $\begin{array}{l}\text { Test of validity of randomization through description of relevant demographic and prognostic variables in experimental and control } \\
\text { group (28) }\end{array}$ & 24 & 86 \\
\hline Methods used to evaluate success of masking (20) & 15 & 75 \\
\hline Methods used to ascertain compliance to treatment (0) & - & - \\
\hline Laboratory tests to evaluate absorption or pharmacological effect of the treatment (16) & 2 & 13 \\
\hline More than one observer evaluating subjective endpoints (23) & 2 & 19 \\
\hline \multicolumn{3}{|l|}{ Data analysis and presentation } \\
\hline Start and stop dates (28) & 20 & 71 \\
\hline Analysis of results of randomization through baseline comparability of the study groups (28) & 17 & 61 \\
\hline Presentation of test statistics and $P$-value (28) & 26 & 93 \\
\hline Discussion of $\beta$ error in negative trials (17) & 3 & 18 \\
\hline Calculation of estimate of variance and/or confidence limits of trials endpoints (28) & 10 & 36 \\
\hline Regression/correlation analysis (25) & 12 & 48 \\
\hline Overall assessment of quality of statistical analysis (28) & 1 & 4 \\
\hline Number of patients who withdrew and the reasons why (28) & 25 & 89 \\
\hline Ways withdrawals were handled (23) & 1 & 4 \\
\hline Side effects reported and analyzed (28) & 6 & 21 \\
\hline Analysis of subgroups not specified at the beginning of the study (retrospective & 2 & 7 \\
\hline
\end{tabular}

Number of studies for which item was applicable in parenthesis

${ }^{*}$ Completely addressed the issue 


\begin{tabular}{|c|c|c|c|c|c|c|c|c|c|c|}
\hline \multirow[b]{2}{*}{ VAP $^{t}$ Prevention } & \multicolumn{5}{|c|}{ Antiseptics } & \multicolumn{5}{|c|}{ Antibiotics } \\
\hline & $\begin{array}{l}\text { No. } \\
\text { Studies }\end{array}$ & $\begin{array}{l}\text { No. } \\
\text { Patients }\end{array}$ & $\begin{array}{l}\text { Overall Risk } \\
\text { Ratio } \\
\text { (Efficacy, } \\
\% \text { ) }\end{array}$ & $\begin{array}{l}\text { 95\% Confidence } \\
\text { Interval (Efficacy } \\
\text { interval,\%) }\end{array}$ & $\begin{array}{l}\text { Heterogeneity } \\
\text { Test }\left(Q ; P ; I^{2},\right. \\
\%)\end{array}$ & $\begin{array}{l}\text { No. } \\
\text { Studies }\end{array}$ & $\begin{array}{l}\text { No. } \\
\text { Patients }\end{array}$ & $\begin{array}{l}\text { Overall Risk } \\
\text { Ratio (Efficacy, } \\
\%)\end{array}$ & $\begin{array}{l}\text { 95\% Confidence } \\
\text { Interval (Efficacy } \\
\text { interval, \%) }\end{array}$ & $\begin{array}{l}\text { Heterogeneity } \\
\text { Test }\left(Q ; P ; I^{2} \text {, }\right. \\
\%)\end{array}$ \\
\hline All studies & 11 & 3,258 & $0.73(27)$ & 0.63 to 0.84 (16 to 37 ) & $13.78 ; 0.18 ; 27.4$ & 15 & 2,463 & $0.64(36)$ & 0.5 to 0.82 (18 to 50$)$ & $\begin{array}{l}47.09 ;<0.001 \\
70.3\end{array}$ \\
\hline High quality & 6 & 2,161 & $0.77(23)$ & 0.66 to 0.9 (10 to 34$)$ & $4.62 ; 0.46 ; 0$ & 11 & 2,249 & $0.69(31)$ & 0.54 to 0.89 (11 to 46$)$ & $\begin{array}{l}34.66 ;<0.001 \\
71.2\end{array}$ \\
\hline Low quality & 5 & 1,097 & $0.6(40)$ & 0.44 to 0.82 (18 to 56$)$ & $8.99 ; 0.06 ; 55.5$ & 4 & 214 & $0.35(65)$ & 0.14 to 0.86 (14 to 86$)$ & $5.64 ; 0.13 ; 46.8$ \\
\hline Only specialty surgery ICU* & 4 & 1,966 & $0.52(48)$ & 0.38 to 0.71 (29 to 62 ) & $3.55 ; 0.31 ; 15.5$ & 3 & 260 & $0.4(60)$ & 0.2 to 0.8 (20 to 80$)$ & $5.64 ; 0.06 ; 64.6$ \\
\hline Only trauma patients & $N A^{\ddagger}$ & - & - & - & - & 4 & 354 & $0.6(40)$ & 0.38 to 0.93 (7 to 62 ) & $8.2 ; 0.04 ; 63.4$ \\
\hline Mixed ICU* & 6 & 1,117 & $0.82(18)$ & 0.68 to 1.00 (0 to 32$)$ & $5.77 ; 0.33 ; 13.3$ & 6 & 1,318 & $0.7(30)$ & 0.46 to 1.05 (-5 to 54$)$ & $13.41 ; 0.02 ; 62.7$ \\
\hline Only double blinded studies & \multicolumn{5}{|c|}{ Same high quality meta-analysis } & 12 & 2,277 & $0.67(33)$ & 0.52 to $0.87(13$ to 48$)$ & $\begin{array}{l}39.53 ;<0.001 \\
72.2\end{array}$ \\
\hline Not double blinded studies & \multicolumn{5}{|c|}{ Same low quality meta-analysis } & 3 & 186 & $0.44(56)$ & 0.21 to 0.92 (8 to 79 ) & $2.83 ; 0.24 ; 29.3$ \\
\hline \multicolumn{11}{|l|}{$\begin{array}{l}\text { Using same antibiotics } \\
\text { combination: }\end{array}$} \\
\hline $\begin{array}{l}\text { Cyclic peptide }+ \\
\text { aminoglycoside }+ \text { polyene } \\
\text { antifungal drug }\end{array}$ & - & - & - & - & - & 6 & 782 & $0.60(40)$ & 0.35 to 1.04 (-4 to 65$)$ & $\begin{array}{l}22.21 ;<0.001 ; \\
77.5\end{array}$ \\
\hline $\begin{array}{l}\text { Vancomycin + other } \\
\text { antimicrobial agents }\end{array}$ & - & - & - & - & - & 3 & 401 & $0.43(57)$ & 0.24 to 0.78 (22 to 76 ) & $5.3 ; 0.07 ; 62.3$ \\
\hline $\begin{array}{l}\text { Digestive tract decontamination } \\
\text { with antibiotics }\end{array}$ & - & - & - & - & - & 11 & 2,172 & $0.67(33)$ & 0.5 to 0.9 (10 to 50$)$ & $\begin{array}{l}35.99 ;<0.001 \\
72.2\end{array}$ \\
\hline $\begin{array}{l}\text { Respiratory tract } \\
\text { decontamination with antibiotics }\end{array}$ & - & - & - & - & - & 4 & 291 & $0.54(46)$ & 0.3 to 0.97 (3 to 97 ) & $9.67 ; 0.02 ; 69$ \\
\hline \multicolumn{11}{|l|}{ Mortality } \\
\hline All studies & 12 & 3,224 & $1.1(-10)$ & 0.98 to 1.24 (-24 to 2$)$ & $9.89 ; 0.54 ; 0$ & 17 & 6,403 & $1.02(-2)$ & 0.93 to 1.13 ( -13 to 7$)$ & $9.82 ; 0.88 ; 0$ \\
\hline High quality & 6 & 2,132 & $1.09(-9)$ & 0.9 to $1.32(-32$ to 10$)$ & $3.59 ; 0.61 ; 0$ & 12 & 2,295 & $1.06(-6)$ & 0.94 to $1.2(-20$ to 6$)$ & $8.55 ; 0.66 ; 0$ \\
\hline Low quality & 6 & 1,192 & $1.11(-11)$ & 0.96 to 1.29 (-29 to 4$)$ & $6.27 ; 0.28 ; 20.3$ & 5 & 4,108 & $0.97(3)$ & 0.84 to $1.12(-12$ to 16$)$ & $0.38 ; 0.98 ; 0$ \\
\hline Only ICU* mortality & 8 & 1,751 & $1.08(-8)$ & 0.92 to 1.26 (-26 to 8$)$ & $4.9 ; 0.67 ; 0$ & 14 & 5,878 & $1.01(-1)$ & 0.9 to $1.12(-12$ to 10$)$ & $9.39 ; 0.74 ; 0$ \\
\hline Only in-hospital mortality & 4 & 1,573 & $0.95(5)$ & 0.95 to 1.37 (-37 to 5$)$ & $4.74 ; 0.19 ; 36.7$ & 6 & 4,768 & $0.98(2)$ & 0.88 to 1.09 (-9 to 12$)$ & $2.43 ; 0.79 ; 0$ \\
\hline Only double blinded studies & \multicolumn{5}{|c|}{ Same high quality meta-analysis } & 13 & 2,323 & $1.06(-6)$ & 0.94 to $1.2(-20$ to 6$)$ & $8.59 ; 0.74 ; 0$ \\
\hline Not double blinded studies & \multicolumn{5}{|c|}{ Same low quality meta-analysis } & 4 & 4,080 & $0.97(3)$ & 0.84 to $1.12(-12$ to 16$)$ & $0.37 ; 0.95 ; 0$ \\
\hline \multicolumn{11}{|l|}{$\begin{array}{l}\text { Using same antibiotics } \\
\text { combination: }\end{array}$} \\
\hline $\begin{array}{l}\text { Cyclic peptide }+ \\
\text { aminoglycoside }+ \text { polyene } \\
\text { antifungal drug }\end{array}$ & - & & - & - & - & 7 & 4,676 & $0.99(1)$ & 0.89 to 1.09 (-9 to 11$)$ & $2.62 ; 0.85 ; 0$ \\
\hline $\begin{array}{l}\text { Vancomycin + other } \\
\text { antimicrobial agents }\end{array}$ & - & - & - & - & - & 3 & 401 & $0.89(11)$ & 0.59 to 1.35 (-35 to 41$)$ & $1.06 ; 0.59 ; 0$ \\
\hline
\end{tabular}


Table 4 Meta-analysis results of effectiveness of topical decontamination in reducing VAP, mortality and all ICU-acquired infections (Continued)

\begin{tabular}{|c|c|c|c|c|c|c|c|c|c|c|}
\hline $\begin{array}{l}\text { Digestive tract decontamination } \\
\text { with antibiotics }\end{array}$ & - & - & - & - & - & 13 & 6,112 & $1.01(-1)$ & 0.92 to $1.12(-12$ to 8$)$ & $6.72 ; 0.87 ; 0$ \\
\hline $\begin{array}{l}\text { Respiratory tract } \\
\text { decontamination with antibiotics }\end{array}$ & - & - & - & - & - & 4 & 291 & $1.17(-17)$ & 0.85 to 1.61 (-61 to 15$)$ & $2.36 ; 0.5 ; 0$ \\
\hline \multicolumn{11}{|l|}{ All ICU*-Acquired infections } \\
\hline All studies & 4 & 1,595 & $1.02(-2)$ & 0.41 to 2.51 (-151 to 59$)$ & $\begin{array}{l}20.14 ;<0.001 ; \\
85.1\end{array}$ & 9 & 4,774 & $0.71(29)$ & 0.59 to 0.86 (14 to 41$)$ & 18.62; 0.02; 57 \\
\hline High quality & 3 & 1,535 & $0.59(41)$ & 0.47 to 0.76 (0.24 to 53$)$ & $3.9 ; 0.14 ; 48.7$ & 7 & 794 & $0.64(36)$ & 0.56 to 0.73 (27 to 44 ) & $7.57 ; 0.27 ; 20.7$ \\
\hline Low quality & $N A^{\ddagger}$ & - & - & - & - & 2 & 3,980 & $0.89(11)$ & 0.52 to 1.52 (-52 to 48$)$ & $6.57 ; 0.01 ; 84.8$ \\
\hline Only specialty surgery ICU* & 2 & 1,307 & $0.55(45)$ & 0.43 to 0.72 (28 to 57 ) & $1.19 ; 0.28 ; 16$ & 4 & 340 & $0.71(29)$ & 0.45 to 1.11 (-11 to 55$)$ & $\begin{array}{l}12.15 ; 0.007 ; \\
75.3\end{array}$ \\
\hline Mixed ICU* & 2 & 288 & $3.02(-202)$ & $\begin{array}{l}0.34 \text { to } 27.12 \\
(-2.61 \text { to } 66)\end{array}$ & $8.2 ; 0.004 ; 87.8$ & 3 & 4,181 & $0.7(30)$ & 0.59 to 0.85 (15 to 41$)$ & $0.65 ; 0.72 ; 0$ \\
\hline \multicolumn{11}{|l|}{$\begin{array}{l}\text { Using same antibiotics } \\
\text { combination: }\end{array}$} \\
\hline $\begin{array}{l}\text { Cyclic peptide }+ \\
\text { aminoglycoside }+ \text { polyene }+ \\
\text { antifungal drug }\end{array}$ & - & - & - & - & - & 3 & 4,103 & $0.66(34)$ & 0.57 to 0.76 (24 to 43 ) & $1.91 ; 0.38 ; 0$ \\
\hline $\begin{array}{l}\text { Vancomycin }+ \text { other } \\
\text { antimicrobial agents }\end{array}$ & - & - & - & - & - & 2 & 349 & $0.53(43)$ & 0.44 to 0.74 (26 to 56 ) & $0.07 ; 0.79 ; 0$ \\
\hline $\begin{array}{l}\text { Digestive tract decontamination } \\
\text { with antibiotics }\end{array}$ & - & - & - & - & - & 7 & 4,584 & $0.7(30)$ & 0.58 to 0.84 (16 to 42 ) & $14.11 ; 0.03 ; 57.5$ \\
\hline $\begin{array}{l}\text { Respiratory tract } \\
\text { decontamination with antibiotics }\end{array}$ & - & - & - & - & - & 2 & 190 & $0.87(13)$ & 0.22 to 3.35 (-235 to 78$)$ & $3.95 ; 0.05 ; 74.7$ \\
\hline
\end{tabular}

* Intensive care units, ${ }^{\dagger}$ ventilator associated pneumonia, ${ }^{\ddagger}$ not applicable because only one study belongs to this group. 


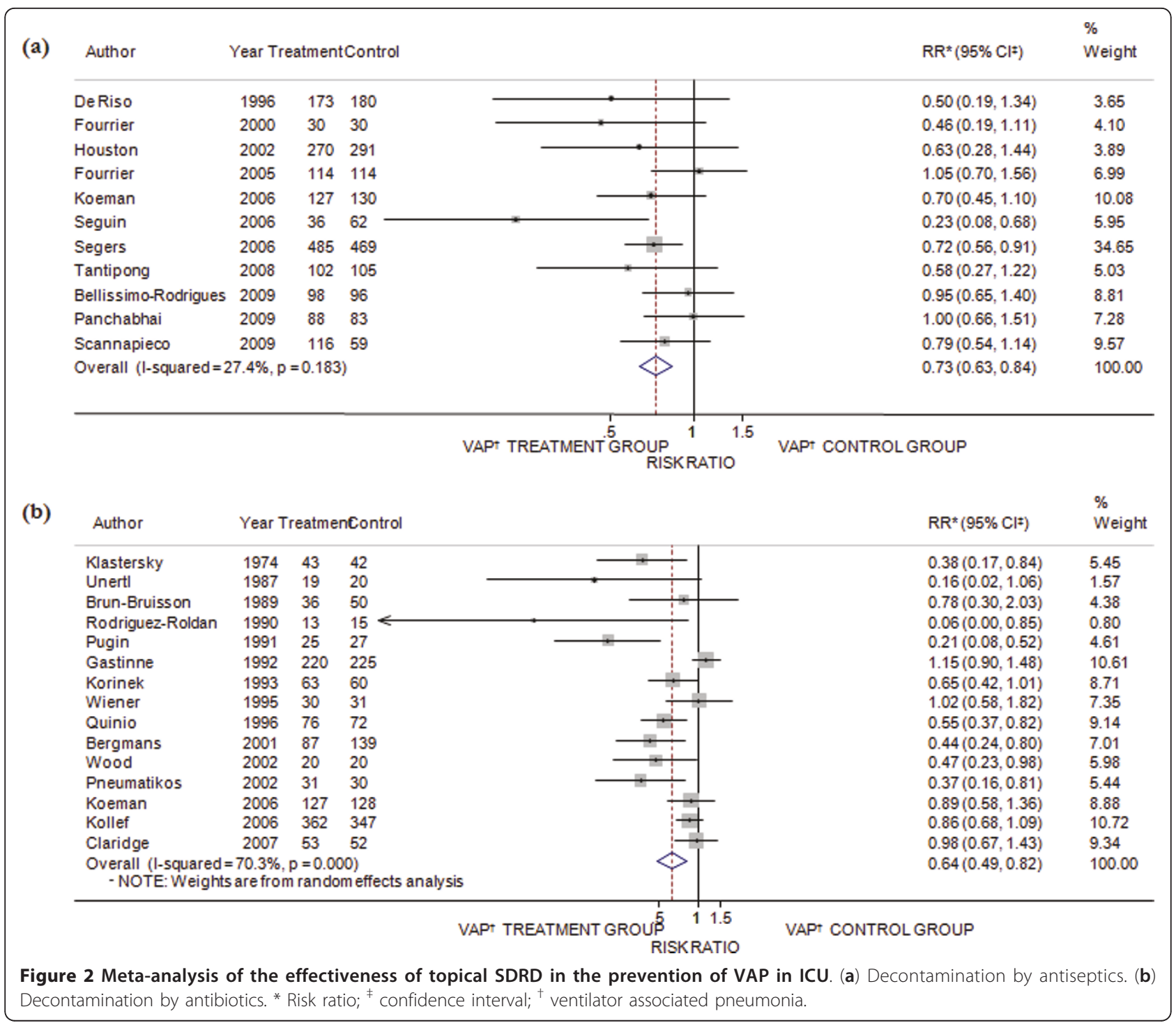

compared to that found in the high quality trials both with antiseptics and antibiotics agents.

Sensitivity analyses were conducted to determine whether the efficacy of chlorhexidine was correlated to dose $(0.12 \%$ vs $0.20 \%$ or $2 \%$ preparations; twice a day application vs three or four applications a day). The results showed a 31\% significant incidence reduction of VAP $(95 \%$ CI of efficacy $=3 \%$ to $51 \%$; $Q=0.91 P=0.63$; $\left.\mathrm{I}^{2}=0 \%\right)$ even using the lowest concentration of chlorhexidine (twice a day application of $0.12 \%$ chlorhexidine gluconate) (data not shown).

Pooled analysis after restriction to specific settings showed that, both for antiseptics and antibiotics, the highest efficacy was found in specialty surgical ICUs and the lowest in mixed ICUs.

The separate meta-analyses involving digestive tract decontamination by antibiotics showed lower efficacy as compared to respiratory tract decontamination by antibiotics.

Finally, we tested the effectiveness of similar combinations of topical antibiotics on VAP prevention and only in the trials that used vancomycin combined with other antimicrobial agents, a significant VAP reduction was found. Overall, low heterogeneity was revealed in almost all sensitivity analyses involving antiseptics, whereas a significant heterogeneity remained in the results among trials on antibiotic prophylaxis of VAP.

\section{Mortality}

In none of the meta-analyses conducted on mortality was a significant effect found.

\section{All ICU-acquired infections}

Four studies on antiseptics contributed to the analysis of all ICU-acquired infections prevention $[51,52,54,56]$ (Figure 3 ) and indicated no statistically significant 


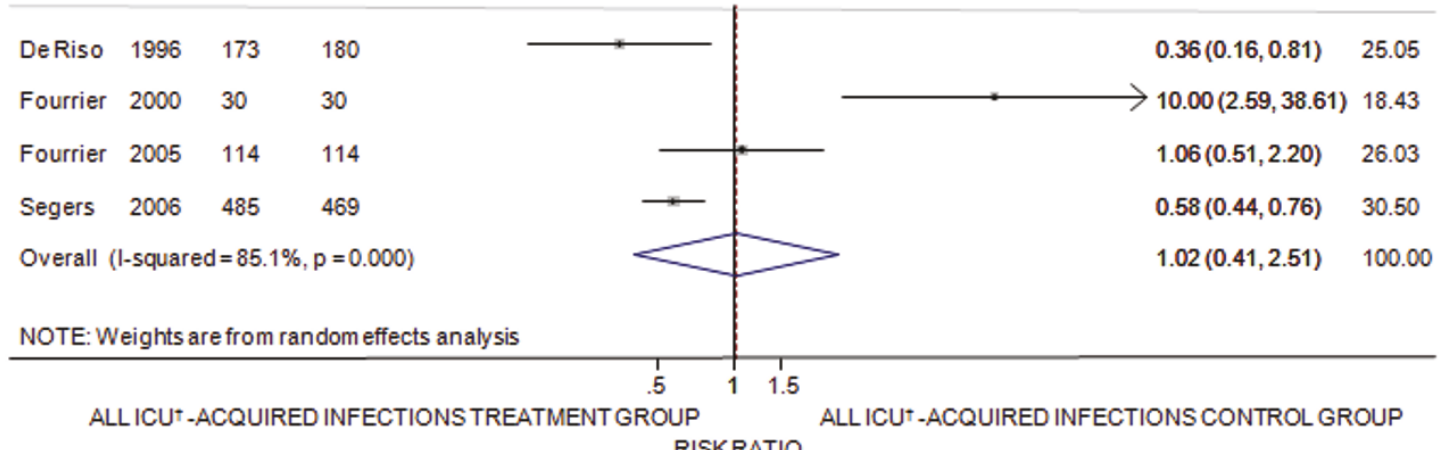

(b)

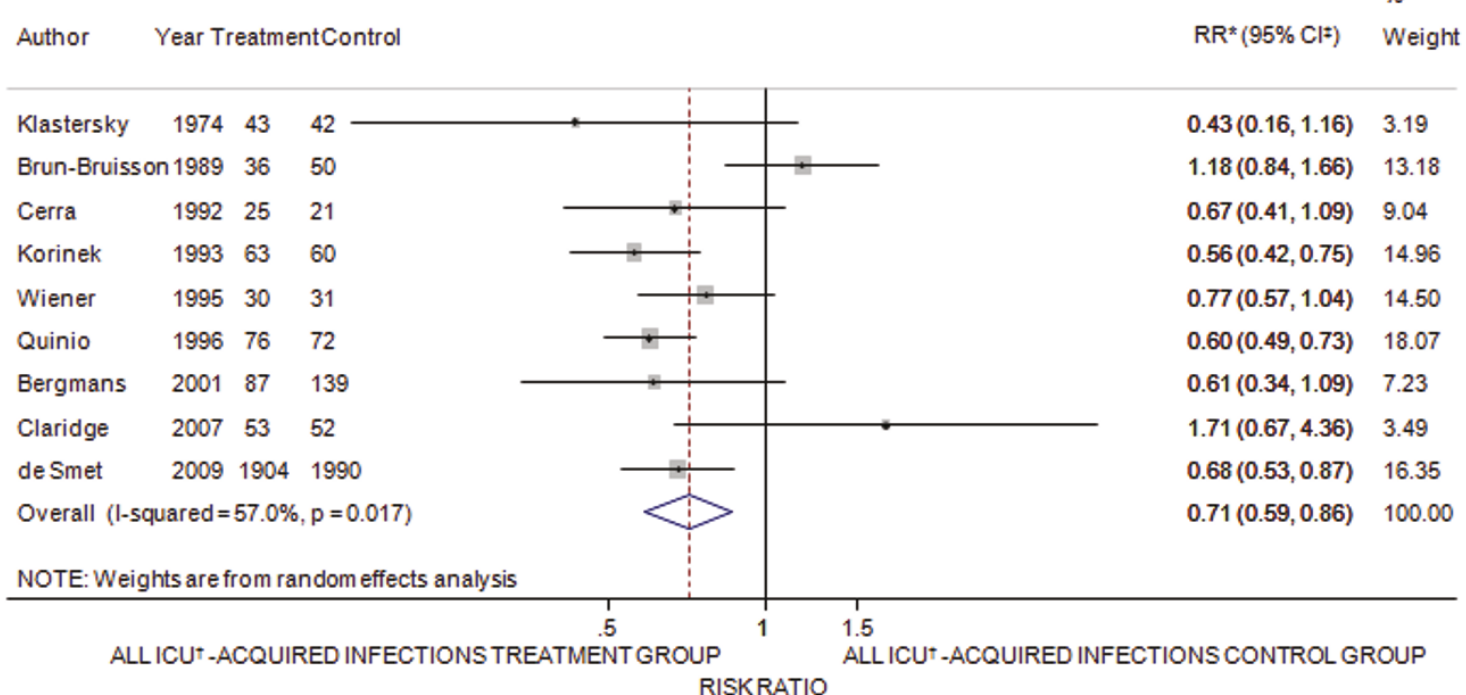

Figure 3 Meta-analysis of the effectiveness of topical SDRD in the prevention of all ICU-acquired infections. (a) Decontamination by antiseptics. (b) Decontamination by antibiotics. ${ }^{*}$ Risk ratio; ${ }^{\ddagger}$ confidence interval; ${ }^{\dagger}$ intensive care units.

beneficial effect of the experimental treatment (efficacy $=-2 \% ; 95 \% \mathrm{CI}$ of efficacy $=-151 \%$ to $59 \% ; \mathrm{Q}=20.14 P$ $\left.<0.001 ; \mathrm{I}^{2}=85.1 \%\right)$. If the analysis was restricted to high quality studies, the efficacy to prevent all ICUacquired infections was $41 \%$ (95\% CI of efficacy $=24 \%$ to $53 \%$ ) and a reduction of heterogeneity among studies became evident $\left(\mathrm{Q}=3.9 P=0.14 ; \mathrm{I}^{2}=48.7 \%\right)$. Similarly, studies involving only specialty surgery ICU showed a significant decrease of all ICU-acquired infections, with a value of $45 \%$ ( $95 \%$ CI of efficacy $=28 \%$ to $57 \%$ ).

Nine trials that tested antibiotic prophylaxis were available for the analysis of all ICU-acquired infections [37,38,58,60,64-68] (Figure 3) and a significant decline in all ICU-acquired infection rate was demonstrated (efficacy $=29 \%$; $95 \%$ CI of efficacy $=14 \%$ to $41 \%$; $Q=$ $\left.18.62 P=0.02 ; \mathrm{I}^{2}=57 \%\right)$. Sensitivity analyses proved an efficacy of the treatment only in the high quality studies when only the digestive tract decontamination was taken into account, when the analysis was restricted to mixed ICU, and to similar conclusion led the meta-analyses limited to research that used the same antibiotic combinations, cyclic peptide plus aminoglycoside plus polyene antifungal drug and vancomycin plus other antimicrobial agents. In most restricted analyses, heterogeneity disappeared.

\section{Other VAP related outcomes}

VAP is important not only if it increases mortality, but also the length of hospital stay, duration of mechanical ventilation, use of antibiotics, quality of life and the length of ICU stay. We tentatively tried to extract data on some of these outcomes from the included trials and we could perform meta-analyses on the duration of mechanical ventilation and length of ICU stay. However, data on duration of mechanical ventilation were 
available only in two antiseptics trials [36,55] and in four antibiotics trials $[62,67,69,70]$ and gave a non-significant effect with a mean difference (MD) for antiseptic use of -0.19 days $\left(95 \% \mathrm{CI}=-0.46\right.$ to $0.07 ; \mathrm{Q}=0.07 \mathrm{P}=0.79 ; \mathrm{I}^{2}$ $=0 \%$ ) and for antibiotic use of -0.12 days (95\% CI = -0.34 to $\left.0.11 ; \mathrm{Q}=0.54 P=0.91 ; \mathrm{I}^{2}=0 \%\right)$. Data on length of ICU stay were available in three studies using antiseptics $[36,55,56]$ and in six studies using antibiotics $[60,62-64,67,69]$. Pooled analyses of these trials did not show an influence on the mean difference of length of ICU stay both for antiseptics $(\mathrm{MD}=-0.7$ days; $95 \% \mathrm{CI}=$ -0.19 to $\left.0.04 ; \mathrm{Q}=0.4 P=0.81 ; \mathrm{I}^{2}=0 \%\right)$ and antibiotics $(\mathrm{MD}=-0.34$ days; $95 \% \mathrm{CI}=-0.73$ to $0.05 ; \mathrm{Q}=27.67 P$ $\left.<0.001 ; \mathrm{I}^{2}=81.9 \%\right)$.

\section{Publication bias}

Funnel plots showed no significant asymmetry for studies exploring the preventive role of antiseptics and of antibiotics.

\section{Discussion \\ VAP}

The major finding of the present meta-analysis provides support to the observation that topical antiseptic or antibiotic SDRD plays a significant role as a protective factor against the development of VAP.

Chlorhexidine has been used as a degerming agent in all but one antiseptic trial, because it has a high level of antibacterial, antiviral and antifungal activity, it is virtually free of adverse effects [72] and it is an inexpensive solution. Seguin et al. used povidone-iodine, another antiseptic agent that has high, rapid and persistent activity on Gram-negative and Gram-positive bacteria $[73,74]$, and it is simple and safe to use [75]. Our results do not allow us to determine which of the two antiseptics has a greater effect, but confirmed the preventive role of antiseptics against VAP. To find the best disinfectant further studies are needed comparing povidoneiodine and chlorhexidine in preventing VAP in "head to head" trials.

The findings of this pooled analysis are consistent with the relatively strong protective association observed between antiseptic oropharyngeal decontamination and the risk of VAP observed in previous meta-analyses [25-28].

Since the pathogenesis of VAP is related to contamination of the aero-digestive tract, our meta-analyses on antibiotics were conducted combining data on topical digestive and respiratory tract decontamination and our findings showed a significant protective effect of the antibiotics. This result persisted when we considered separately the digestive and the respiratory tract decontamination, suggesting that any of these two ways of decontamination may be used. Only two studies $[57,70]$ classified VAP according to time of onset in early and late-onset [76]; therefore, we have not performed a sensitivity analysis on this issue.

Comparisons with the results of previous meta-analyses are very difficult since the inclusion criteria used were different. Indeed, Liberati et al. [31] did not make any restriction on the type of respiratory tract infections (RTIs), combining trials on pneumonia and tracheobronchitis in ICU patients, nor on unpublished RCT or on language, whereas they restricted inclusion to digestive decontamination by antibiotics only. The results of Liberati et al. showed a significant protective effect on RTIs.

Chan et al. [27] did not reach our conclusions since their results suggested no significant protective effect of topical antibiotic prophylaxis on VAP. Indeed, the metaanalysis of Chan et al. had only two studies [68,71] in common with ours, and pooled 1,098 patients, whereas the present meta-analysis could take into account a larger sample size (2,463 patients). Finally, Falagas et al. [30], who took into account only the effect of administration of antimicrobial agents via the respiratory tract, concluded that pneumonia occurred significantly less often in the prophylaxis arm compared to the comparison arm. Our sub-analysis on trials that tested respiratory tract decontamination confirms these results, even if the sample analyzed is different because we included only pneumonia occurring in patients assisted by mechanical ventilation; therefore, we excluded the trials of Greenfield et al. [77] because data on colonization only was reported and of Klick et al. [78] for incomplete data on outcomes. Moreover, we excluded non-randomized trials [79] and abstracts [80], and included one study in which the preventive strategy was topical decontamination in the subglottic area [70], and a recent trial that tested prophylactic administration of aerosolized ceftazidime [37].

\section{Mortality}

In the present meta-analysis neither antibiotic nor antiseptic topical decontamination influenced overall mortality, and the results did not substantially differ in the separate meta-analyses performed according to different quality and study design or details of intervention. Liberati et al., in previously published meta-analysis, examining the prophylactic use of antibiotics, have shown efficacy in reducing mortality when topical decontamination was combined with intravenous antibiotic administration, whereas, in line with our results, topical prophylaxis alone was not effective. No former metaanalyses on antiseptics or antibiotics [27-29,31] showed a significant beneficial effect on mortality.

These results could be due to lack of an effect of administration of topical agents on mortality since in only one trial that used antiseptic decontamination [51], 
and in no antibiotic trials [37,38,57-71], was a significant reduction in mortality found. Another possible explanation was that in most of the trials mortality was a secondary outcome and data accuracy could be lower than primary outcome; therefore, analysis combining these data could have failed to show an effect of experimental treatment. Also, in our case the overall sample size was small and, therefore, could have limited the interpretation of the effect on mortality. Another possible explanation can be related to our inability to distinguish the role of the topical SDRD on the occurrence of early and late-onset VAP. It has been demonstrated that VAP related mortality is restricted mainly to patients with late-onset VAP; it is only marginally reduced with appropriate empirical antibiotic treatment [14]. In the same study the authors report that the prophylactic regimen they used, that is, the universal use of continuous aspiration of subglottic secretions, was recognized to be a reducing and delaying factor for VAP. Therefore, we may hypotheses that if the topical SDRD is also particularly effective only on the reduction of early-onset VAP, its role on late-onset VAP related mortality may be marginal. Trials allowing data extraction on the occurrence of early and late-onset VAP separately are strongly needed.

\section{All ICU-acquired infections}

To the best of our knowledge, this is the first meta-analysis aimed at the assessment of the effectiveness of topical SDRD on the incidence of all ICU-acquired infections.

Our results have shown the effectiveness of topical SDRD both with antiseptics, although only in the sensitivity analyses restricted to high quality studies and to those involving only specialty surgery ICU, and antibiotics.

These achievements confirmed what we expected because colonization is a prerequisite for the development of infections that frequently arises from the endogenous flora in the oropharyngeal and intestinal tract; therefore, healthcare-associated infections were potentially preventable through the suppression of colonization of the digestive and/or the respiratory tract. Also, nosocomial pneumonia is the second most common healthcare-associated infections (HAI) and the most frequently acquired infection in the ICU, so all ICUacquired infections could be reduced secondarily from a VAP prevention.

\section{Resistance to antiseptic and antimicrobial agents}

Considering the importance of antibiotic-resistance in ICUs, we focused our interest on topical administration since it has been reported that it is more frequent when a combination of topical plus systemic antibiotics was used $[81,82]$ rather than only topical antibiotics $[38,83]$. Anyway, the biggest criticism even against topical SDRD is the emergence of resistant strains. This issue has been only marginally investigated in most of the studies included in the meta-analysis. The majority of the trials using antibiotics $[37,38,57,59,61,62,64,68,69]$ found no increase in infections caused by antibiotic-resistant organisms, at least during the relatively short period of studies, whereas a trend towards increased colonization of patients by resistant microbial strains was reported $[58,66,67]$. This increase was not found in studies using antiseptics $[37,51,52,57]$. On the basis of these results, a long-term increase in the occurrence of HAIs sustained by resistant strains as a result of topical SDRD with antibiotics cannot be excluded, and this issue warrants cautious attention in further studies. However, it should be pointed out that routine five-year use of selective digestive decontamination was not associated with increased antimicrobial resistance rates [83]. This finding allows us to suggest an analogous result with the use of long-term topical SDRD at least in ICU with low baseline resistance rates.

\section{Strengths and limitations of the study}

The strengths of the present meta-analysis include the considerable number of studies and subjects included as well as the acceptable methodologic quality of the studies on which the analysis is based. It is well-known that the quality assessment of the primary studies has been identified as one of the most important steps of the peer-review process [84]. This comes from the consideration that studies of poor quality may yield information that is not valid; therefore, the inclusion of studies with invalid information in a meta-analysis can make the conclusion of the meta-analysis invalid. Therefore, taking the quality of studies into account in a meta-analysis has the potential to enhance the validity of a meta-analysis because quality is implicitly a measure of validity [85]. Moreover, the evaluation of the quality of the studies in a meta-analysis may contribute to point out limitations in published studies and suggest ways to improve the methodology of studies in further research. In this meta-analysis the quality of the RCTs was good with regard to the various methodological aspects of the research protocol (for example, description of therapeutic regimen, criteria for patient selection, randomization, blinding) while the main shortcomings were related to the overall assessment of the statistical methods and presentation of data. Limitations of the present meta-analysis study include the heterogeneity between the studies with respect to patient populations that had a different profile of risk factors; different medications used, particularly in antibiotic trials, in the choice of the 
antimicrobial agents or their associations or the delivery mode; different approaches for the control arms and different outcome definitions. Moreover, among our inclusion criteria there was restriction to studies published in English. This is a controversial issue, since some argue that authors are more likely to report positive results in international journals and negative results in local journals, as demonstrated by Egger et al. [86]. Language restriction could, therefore, introduce bias in the results of the meta-analysis $[87,88]$. However, there has also been evidence that studies published in local journals may be of lower methodological quality, as reported by Sterne et al. [89], and this would be in favor of their exclusion. We have also performed a search without language restriction and it would have led to the inclusion of two more papers [90,91]. Vogel et al. [90] was excluded because it was not a RCT, while we have repeated the meta-analyses of topical SDRD by antibiotics on VAP prevention and on mortality by entering Rathgeber et al. [91] and the results did not alter our conclusions. Indeed, the overall estimate of efficacy of antibiotics on VAP prevention was $37 \%$ ( $95 \%$ CI of efficacy $=20 \%$ to $51 \%$ ) and the meta-analysis on mortality showed no significant effect (efficacy $=-2 \%$; $95 \%$ CI of efficacy $=-12 \%$ to $7 \%$ ). These results were confirmed in the sensitivity analyses involving only upper respiratory tract decontamination with antibiotics (data not shown). Therefore, we believe that our strategy is not prone to substantial bias or to low robustness in the overall results. Finally, the findings are affected by the limitations of the individual trials included. According to the mentioned limitations, the results of the meta-analysis must be interpreted with caution; however, the careful examination of possible sources of heterogeneity contributed to assess the methodologic quality of research, and to identify potential biases, data gaps, and suggestions for future research.

\section{Conclusions}

In conclusion, despite the above limitations, we think that our results prove that topical SDRD using antiseptics or antimicrobial agents is effective in reducing the frequency of VAP in ICU. Unlike antiseptics, the use of topical antibiotics seems to be effective also in preventing all ICU-acquired infections, while the effectiveness on mortality of these two approaches needs to be investigated in further research. Also, further research is essential to compare different preventive protocols in ICU patients, such as the "head to head" comparison of topical antiseptics and antibiotics, the oral cavity decontamination only compared to the whole digestive tract, or the decontamination of the airways to the digestive tract. Finally, a more careful assessment of the cost- effectiveness of preventive interventions used and a more systematic evaluation of issues related to the emergence of drug resistance are necessary.

\section{Key messages}

- VAP is related to a high rate of morbidity, complications, prolonged ICU stay and mortality in patients receiving mechanical ventilation.

- Colonization of the aerodigestive tract is primarily involved in VAP's pathogenesis and represents a main objective for prevention.

- Topical SDRD using antiseptics or antibiotics is effective in reducing the incidence of VAP in ICU.

- Topical SDRD using antibiotics is effective in reducing the incidence of all ICU-acquired infections.

- Further research is essential to compare different preventive protocols in ICU patients and to assess the cost-effectiveness of preventive intervention used.

\section{Abbreviations}

Cl: confidence intervals; HAls: healthcare-associated infections; MD: mean difference; OR: odds ratio; RCTs: randomized controlled trials; RR: risk ratio; RTIs: respiratory tract infections; SDRD: selective digestive or respiratory tract decontamination; VAP: ventilator-associated pneumonia.

\section{Author details}

'Department of Clinical and Experimental Medicine, Chair of Hygiene, Medical School, University of Catanzaro "Magna Græcia", via Tommaso Campanella, 88100 Catanzaro Italy. ${ }^{2}$ Hospital Hygiene Unit, "Mater Domini" University Hospital, via Tommaso Campanella, 88100 Catanzaro Italy.

\section{Authors' contributions}

CP participated in the conception and design of the study, collected the data, contributed to the data analysis and its interpretation, and wrote the first draft of the article. AB, DF and CGAN collected the data, and contributed to the data analysis and interpretation. MP designed the study, was responsible for the data analysis and interpretation, and wrote the article. CP and MP are guarantors for the study. All authors had full access to all of the data (including statistical reports and tables) in the study and take responsibility for the integrity of the data and the accuracy of the data analysis. All authors have read and approved the manuscript for publication.

\section{Competing interests}

The authors declare that they have no competing interests.

Received: 4 January 2011 Revised: 27 April 2011

Accepted: 24 June 2011 Published: 24 June 2011

\section{References}

1. Vincent JL, Bihari DJ, Suter PM, Bruining HA, White J, Nicolas-Chanoin MH, Wolff M, Spencer RC, Hemmer M: The prevalence of nosocomial infection in intensive care units in Europe: results of the European Prevalence of Infection in Intensive Care (EPIC) Study: EPIC International Advisory Committe. JAMA 1995, 274:639-644.

2. Rebollo MH, Bernal JM, Llorca J, Rabasa JM, Revuelta JM: Nosocomial infections in patients having cardiovascular operations: a multivariate analysis of risk factors. J Thorac Cardiovasc Surg 1996, 112:908-913.

3. Papia G, McLellan BA, El-Helou P, Louie M, Rachlis A, Szalai JP, Simor AE: Infection in hospitalized trauma patients: incidence, risk factors, and complications. J Trauma 1999, 47:923-927. 
4. Legras A, Malvy D, Quinioux Al, Villers D, Bouachour G, Robert R, Thomas R: Nosocomial infections: prospective survey of incidence in five French intensive care units. Intensive Care Med 1998, 24:1040-1046.

5. Girou E, Stephan F, Novara A, Safar M, Fagon JY: Risk factors and outcome of nosocomial infections: results of a matched case-control study of ICU patients. Am J Respir Crit Care Med 1998, 157:1151-1158.

6. Dagan O, Cox PN, Ford-Jones L, Ponsonby J, Bohn DJ: Nosocomial infection following cardiovascular surgery: comparison of two periods, 1987 vs. 1992. Crit Care Med 1999, 27:104-108.

7. Morehead RS, Pinto SJ: Ventilator-associated pneumonia. Arch Intern Med 2000, 160:1926-1936.

8. Craven DE: Preventing ventilator-associated pneumonia in adults. Chest 2006, 130:251-260

9. Chastre J, Fagon JY: Pneumonia in the ventilator-dependent patient. In Principles and practice of mechanical ventilation.. 1 edition. Edited by: Tobin MJ. New York: McGraw-Hill; 1994:857-890.

10. National Nosocomial Infections Surveillance (NNIS) System report, data summary from January 1990-May 1999, issued June 1999. Am J Infect Control 1999, 27:520-532.

11. Rello J, Ollendorf DA, Osler G, Vera-Llonch M, Bellm L, Redman R, Kollef MH: Epidemiology and outcomes of ventilator associated pneumonia in a large US database. Chest 2002, 122:2115-2121.

12. Heyland DK, Cook DJ, Griffith L, Keenan SP, Brun-Buisson C: The attributable morbidity and mortality of ventilator-associated pneumonia in the critically ill patient. The Canadian Critical Trials Group. Am J Respir Crit Care Med 1999, 159:1249-1256.

13. Fagon JY, Chastre J, Hance AJ, Montravers P, Novara A, Gibert C: Nosocomial pneumonia in ventilated patients: a cohort study evaluating attributable mortality and hospital stay. Am J Med 1993, 94:281-288.

14. Valles J, Pobo A, Garcia-Esquirol O, Mariscal D, Real J, Fernandez R: Excess ICU mortality attributable to ventilator-associated pneumonia: the role of early vs late onset. Intensive Care Med 2007, 33:1363-1368.

15. Chastre J, Fagon JY: Ventilator-associated pneumonia. Am J Respir Crit Care Med 2002, 165:867-903

16. Tablan OC, Anderson LJ, Besser R, Bridges C, Hajjeh R: Guidelines for preventing health-care-associated pneumonia, 2003: Recommendations of CDC and the Healthcare Infection Control Practices Advisory Committee. MMWR Recomm Rep 2004, 53:1-36.

17. The American Thoracic Society and the Infectious Diseases Society of America Guideline Committee: Guidelines for the management of adults with hospital-acquired, ventilator-associated, and healthcare-associated pneumonia. Am J Respir Crit Care Med 2005, 171:388-416.

18. Safdar N, Crnich CJ, Maki DG: The pathogenesis of ventilator-associated pneumonia: its relevance to developing effective strategies for prevention. Respir Care 2005, 50:725-739.

19. Bonten MJ, Kollef MH, Hall JB: Risk factors for ventilator-associated pneumonia: from epidemiology to patient management. Clin Infect Dis 2004, 38:1141-1149.

20. Wells Cl, Maddaus MA, Simmons RL: Proposed mechanisms for the translocation of intestinal bacteria. Rev Infect Dis 1988, 10:958-979.

21. Atherton ST, White DJ: Stomach as a source of bacteria colonizing respiratory tract during artificial ventilation. Lancet 1983, 2:968-969.

22. Marshall JC, Christou NV, Horn R, Meakins JL: The microbiology of multiple organ failure. The proximal gastrointestinal tract as an occult reservoir of pathogens. Arch Surg 1988, 123:309-315.

23. Feldman C, Kassel M, Cantrell J, Kaka S, Morar R, Goolam Mahomed A, Philips JI: The presence and sequence of endotracheal tube colonization in patients undergoing mechanical ventilation. Eur Respir J 1999, 13:546-551.

24. Inglis TJ, Millar MR, Jones JG, Robinson DA: Tracheal tube biofilm as a source of bacterial colonization of the lung. J Clin Microbiol 1989, 27:2014-2018.

25. Siempos II, Falagas ME: Oral decontamination with chlorhexidine reduces the incidence of nosocomial pneumonia. Crit Care 2007, 11:402.

26. Chlebicki MP, Safdar N: Topical chlorhexidine for prevention of ventilatorassociated pneumonia: a meta-analysis. Crit Care Med 2007, 35:595-602.

27. Chan EY, Ruest A, Meade MO, Cook DJ: Oral decontamination for prevention of pneumonia in mechanically ventilated adults: systematic review and meta-analysis. BMJ 2007, 334:889.
28. Kola A, Gastmeier P: Efficacy of oral chlorhexidine in preventing lower respiratory tract infections. Meta-analysis of randomized controlled trials. J Hosp Infect 2007, 66:207-216.

29. Pineda LA, Saliba RG, El Solh AA: Effect of oral decontamination with chlorhexidine on the incidence of nosocomial pneumonia: a metaanalysis. Crit Care 2006, 10:R35

30. Falagas ME, Siempos II, Bliziotis IA, Michalopoulos A: Administration of antibiotics via respiratory tract for the prevention of ICU-acquired pneumonia: a meta-analysis of comparative trials. Critical Care 2006, 10: R123.

31. Liberati A, D'Amico R, Pifferi S, Torri V, Brazzi L: Antibiotic prophylaxis to reduce respiratory tract infections and mortality in adults receiving intensive care. Cochrane Database Syst Rev 2004, 1:CD000022.

32. Tantipong $H$, Morkchareonpong C, Jaiyindee $S$, Thamlikitkul V: Randomized controlled trial and meta-analysis of oral decontamination with $2 \%$ chlorhexidine solution for the prevention of ventilator-associated pneumonia. Infect Control Hosp Epidemiol 2008, 29:131-136.

33. Bellissimo-Rodrigues F, Bellissimo-Rodrigues WT, Viana JM, Teixeira GC Nicolini E, Auxiliadora-Martins M, Passos AD, Martinez EZ, Basile-Filho A, Martinez R: Effectiveness of oral rinse with chlorhexidine in preventing nosocomial respiratory tract infections among intensive care unit patients. Infect Control Hosp Epidemiol 2009, 30:952-958.

34. Panchabhai TS, Dangayach NS, Krishnan A, Kothari VM, Karnad DR: Oropharyngeal cleansing with $0.2 \%$ chlorhexidine for prevention of nosocomial pneumonia in critically ill patients: an open-label randomized trial with $0.01 \%$ potassium permanganate as control. Chest 2009, 135:1150-1156

35. Munro CL, Grap MJ, Jones DJ, McClish DK, Sessler CN: Chlorhexidine, toothbrushing, and preventing ventilator-associated pneumonia in critically ill adults. Am J Crit Care 2009, 18:428-437.

36. Scannapieco FA, Yu J, Raghavendran K, Vacanti A, Owens SI, Wood K, Mylotte JM: A randomized trial of chlorhexidine gluconate on oral bacterial pathogens in mechanically ventilated patients. Crit Care 2009, 13:R117.

37. Claridge JA, Edwards NM, Swanson J, Fabian TC, Weinberg JA, Wood C, Croce MA: Aerosolized ceftazidime prophylaxis against ventilator pneumonia in high-risk trauma patients: results of a double blind randomized study. Surg Infect (Larchmt) 2007, 8:83-90.

38. de Smet AM, Kluytmans JA, Cooper BS, Mascini EM, Benus RF, van der Werf TS, van der Hoeven JG, Pickkers P, Bogaers-Hofman D, van der Meer NJ, Bernards AT, Kuijper EJ, Joore JC, Leverstein-van Hall MA Bindels AJ, Jansz AR, Wesselink RM, de Jongh BM, Dennesen PJ, van Asselt GJ, te Velde LF, Frenay IH, Kaasjager K, Bosch FH, van Iterson M, Thijsen SF, Kluge GH, Pauw W, de Vries JW, Kaan JA, et al: Decontamination of the digestive tract and oropharynx in ICU patients. N Engl J Med 2009, 360:20-31.

39. Chalmers TC, Smith H Jr, Blackburn B, Silverman B, Schroeder B, Reitman D, Ambroz A: A method for assessing the quality of a randomized control trial. Controlled Clin Trials 1981, 2:31-49.

40. Jadad AR, Moore RA, Carrol D, Jenkinson C, Reynolds JM, Gavaghan DJ, McQuay HJ: Assessing the quality of reports of randomized clinical trials: is blinding necessary? Controlled Clin Trials 1996, 17:1-12.

41. Fleiss $J$, Cohen $\mathrm{J}$ : The equivalence of weighed kappa and the intraclass correlation coefficient as measures of realibility. Educ Psychol Meas 1973, 33:613-619.

42. Mantel N, Haenszel W: Statistical aspects of the analysis of data from retrospective studies of disease. J Natl Cancer Inst 1959, 22:719-748.

43. DerSimonian R, Laird N: Meta-analysis in clinical trials. Controlled Clin Trials 1986, 7:177-188.

44. Higgins JP, Thompson SC: Quantifying heterogeneity in a meta-analysis. Stat Med 2002, 21:1539-1558.

45. Higgins JP, Thompson SC, Deeks JJ, Altman DG: Measuring inconsistency in meta-analyses. BMJ 2003, 327:557-560.

46. Egger M, Davey Smith G, Schneider M, Minder C: Bias in meta-analysis detected by a simple, graphical test. BMJ 1997, 315:629-634.

47. Sterne JA, Egger M: Funnel plots for detecting bias in meta-analysis: Guidelines on choice of axis. J Clin Epidemio/ 2001, 54:1046-1055.

48. Begg CB, Mazumdar M: Operating characteristics of a rank correlation test for publication bias. Biometrics 1994, 50:1088-1099. 
49. Stata Corporation: Stata Statistical Software: Release 10.0 College Station, TX, USA; 2007.

50. Moher D, Liberati A, Tetzlaff J, Altman DG, The PRISMA Group (2009): Preferred Reporting Items for Systematic Reviews and Meta-Analyses: The PRISMA statement. BMJ 2009, 339:b2535.

51. DeRiso AJ, Ladowski JS, Dillon TA, Justice JW, Peterson AC: Chlorhexidine gluconate $0.12 \%$ oral rinse reduces the incidence of total nosocomial respiratory infection and nonprophylactic systemic antibiotic use in patients undergoing heart surgery. Chest 1996, 109:1556-1561.

52. Fourrier F, Cau-Pottier E, Boutigny H, Roussel-Delvallez M, Jourdain M, Chopin C: Effects of dental plaque antiseptic decontamination on bacterial colonization and nosocomial infections in critically ill patients. Intensive Care Med 2000, 26:1239-1247.

53. Houston S, Hougland P, Anderson JJ, LaRocco M, Kennedy V, Gentry LO: Effectiveness of $0.12 \%$ chlorhexidine gluconate oral rinse in reducing prevalence of nosocomial pneumonia in patients undergoing heart surgery. Am J Crit Care 2002, 11:567-570.

54. Fourrier $F$, Dubois D, Pronnier P, Herbecq P, Leroy $O$, Desmettre $T$, PottierCau E, Boutigny H, Di Pompéo C, Durocher A, Roussel-Delvallez M, PIRAD Study Group: Effect of gingival and dental plaque antiseptic decontamination on nosocomial infections acquired in the intensive care unit: a double-blind placebo-controlled multicenter study. Crit Care Med 2005, 33:1728-1735.

55. Seguin P, Tanguy M, Laviolle B, Tirel O, Mallédant Y: Effect of oropharyngeal decontamination by povidone-iodine on ventilatorassociated pneumonia in patients with head trauma. Crit Care Med 2006, 34:1514-1519.

56. Segers P, Speekenbrink RG, Ubbink DT, van Ogtrop ML, de Mol BA: Prevention of nosocomial infection in cardiac surgery by decontamination of the nasopharynx and oropharynx with chlorhexidine gluconate: a randomized controlled trial. JAMA 2006, 296:2460-2466.

57. Koeman M, van der Ven AJ, Hak E, Joore HC, Kaasjager K, de Smet AG, Ramsay G, Dormans TP, Aarts LP, de Bel EE, Hustinx WN, van der Tweel I, Hoepelman AM, Bonten MJ: Oral decontamination with chlorhexidine reduces the incidence of ventilator-associated pneumonia. Am J Respir Crit Care Med 2006, 173:1348-1355.

58. Klastersky J, Huysmans E, Weerts D, Hensgens C, Daneau D: Endotracheally administered gentamicin for the prevention of infections of the respiratory tract in patients with tracheostomy: a double-blind study. Chest 1974, 65:650-654.

59. Unertl K, Ruckdeschel G, Selbmann HK, Jensen U, Forst H, Lenhart FP, Peter K: Prevention of colonization and respiratory infections in longterm ventilated patients by local antimicrobial prophylaxis. Intensive Care Med 1987, 13:106-113.

60. Brun-Buisson C, Legrand P, Rauss A, Richard C, Montravers F, Besbes M, Meakins JL, Soussy CJ, Lemaire F: Intestinal decontamination for control of nosocomial multiresistant gram-negative bacilli. Study of an outbreak in an intensive care unit. Ann Intern Med 1989, 110:873-881.

61. Rodríguez-Roldán JM, Altuna-Cuesta A, López A, Carrillo A, Garcia J, León J, Martínez-Pellús AJ: Prevention of nosocomial lung infection in ventilated patients: use of an antimicrobial pharyngeal nonabsorbable paste. Crit Care Med 1990, 18:1239-1242.

62. Pugin J, Auckenthaler R, Lew DP, Suter PM: Oropharyngeal decontamination decreases incidence of ventilator-associated pneumonia. A randomized, placebo-controlled, double-blind clinical trial. JAMA 1991, 265:2704-2710.

63. Gastinne H, Wolff M, Delatour F, Faurisson F, Chevret $S$ : A controlled trial in intensive care units of selective decontamination of the digestive tract with nonabsorbable antibiotics. The French Study Group on Selective Decontamination of the Digestive Tract. N Engl J Med 1992, 326:594-599.

64. Cerra FB, Maddaus MA, Dunn DL, Wells CL, Konstantinides NN, Lehmann SL, Mann HJ: Selective gut decontamination reduces nosocomial infections and length of stay but not mortality or organ failure in surgical intensive care unit patients. Arch Surg 1992, 127:163-167.

65. Korinek AM, Laisne MJ, Nicolas MH, Raskine L, Deroin V, Sanson-Lepors MJ: Selective decontamination of the digestive tract in neurosurgical intensive care unit patients: a double-blind, randomized, placebocontrolled study. Crit Care Med 1993, 21:1466-1473.

66. Wiener J, Itokazu G, Nathan C, Kabins SA, Weinstein RA: A randomized, double-blind, placebo-controlled trial of selective digestive decontamination in a medical-surgical intensive care unit. Clin Infect Dis 1995, 20:861-867.

67. Quinio B, Albanèse J, Bues-Charbit M, Viviand X, Martin C: Selective decontamination of the digestive tract in multiple trauma patients. $A$ prospective double-blind, randomized, placebo-controlled study. Chest 1996, 109:765-772.

68. Bergmans DC, Bonten MJ, Gaillard CA, Paling JC, van der Geest S, van Tiel FH, Beysens AJ, de Leeuw PW, Stobberingh EE: Prevention of ventilator-associated pneumonia by oral decontamination: a prospective, randomized, double-blind, placebo-controlled study. Am J Respir Crit Care Med 2001, 164:382-388.

69. Wood GC, Boucher BA, Croce MA, Hanes SD, Herring VL, Fabian TC: Aerosolized ceftazidime for prevention of ventilator-associated pneumonia and drug effects on the proinflammatory response in critically ill trauma patients. Pharmacotherapy 2002, 22:972-982.

70. Pneumatikos I, Koulouras V, Nathanail C, Goe D, Nakos G: Selective decontamination of subglottic area in mechanically ventilated patients with multiple trauma. Intensive Care Med 2002, 28:432-437.

71. Kollef M, Pittet D, Sánchez García M, Chastre J, Fagon JY, Bonten M, Hyzy R, Fleming TR, Fuchs H, Bellm L, Mercat A, Mañez R, Martínez A, Eggimann P, Daguerre M, Luyt CE, Prevention of Pneumonia Study (POPS-1) Trial Group: A randomized double-blind trial of iseganan in prevention of ventilatorassociated pneumonia. Am J Respir Crit Care Med 2006, 173:91-97.

72. Denton GW: Chlorhexidine. In Disinfection, Sterilization, and Preservation.. 5 edition. Edited by: Block SS. Philadelphia, PA: Lippincott Williams 2001:321-326.

73. Shiraishi T, Nakagawa Y: Evaluation of the bactericidal activity of povidone-iodine and commercially available gargle preparations. Dermatology 2002, 204(suppl 1):37-41

74. Ogata J, Minami K, Miyamoto H, Horishita T, Ogawa M, Sata T, Taniguchi H: Gargling with povidone-iodine reduces the transport of bacteria during oral intubation. Can J Anesth 2004, 51:932-936.

75. Slots J: Selection of antimicrobial agents in periodontal therapy. $J$ Periodontal Res 2002, 37:389-398.

76. American Thoracic Society: Hospital-acquired pneumonia in adults: diagnosis, assessment of severity, initial antimicrobial therapy and preventive strategies. A consensus statement. Am J Respir Crit Care Med 1996, 153:1711-1725

77. Greenfield S, Teres D, Bushnell LS, Hedley-White J, Feingold DS: Prevention of gram-negative bacillary pneumonia using aerosol polymyxin as prophylaxis. I. Effect on the colonization pattern of the upper respiratory tract of seriously ill patients. J Clin Invest 1973, 52:2935-2940.

78. Klick JM, du Moulin GC, Hedley-Whyte J, Teres D, Bushnell LS, Feingold DS: Prevention of gram-negative bacillary pneumonia using polymyxin aerosol as prophylaxis. II. Effect on the incidence of pneumonia in seriously ill patients. J Clin Invest 1975, 55:514-519.

79. Rouby JJ, Poète P, Martin de Lassale E, Nicolas MH, Bodin L, Jarlier V, Korinek AM, Viars P: Prevention of gram negative nosocomial bronchopneumonia by intratracheal colistin in critically ill patients. Histologic and bacteriologic study. Intensive Care Med 1994, 20:187-192.

80. Lode H, Goecke J, The PEG-Endotracheal Gentamicin Study Group: Endotracheal application of gentamicin: randomized placebo-controlled double-blind study in ventilated patients. 28th Interscience Conference on Antimicrobial Agents and Chemotheraphy: Los Angeles; 1988, Abstract 30.

81. Verwaest $C$, Verhaegen J, Ferdinande P, Schetz M, Van den Berghe G, Verbist L, Lauwers P: Randomized, controlled trial of selective decontamination in 600 mechanically ventilated patients in a multidisciplinary intensive care unit. Crit Care Med 1997, 25:63-71.

82. Lingnau W, Berger J, Javorsky F, Fille M, Allerberger F, Benzer H: Changing bacterial ecology during a five-year period of selective intestinal decontamination. J Hosp Infect 1998, 39:195-206.

83. Heininger A, Meyer E, Schwab F, Marschal M, Unertl K, Krueger WA: Effects of long-term routine use of selective digestive decontamination on antimicrobial resistance. Intensive Care Med 2006, 32:1569-1576.

84. Kassirer JP, Campion EW: Peer review. Crude and understudied, but indispensable. JAMA 1994, 272:96-97.

85. Laird NM, Mosteller F: Some statistical methods for combining experimental results. Int J Technol Assess Health Care 1990, 6:5-30

86. Egger M, Zellweger-Zahner T, Schneider M, Junker C, Lengeler C, Antes G: Language bias in randomized controlled trials published in English and German. Lancet 1997, 350:326-329. 
87. Moher $D$, Fortin $P$, Jadad $A R$, Jüni $P$, Klassen $T$, Le Lorier J, Liberati $A$, Linde $K$, Penna A: Completeness of reporting of trials published in languages other than English: implications for conduct and reporting of systematic reviews. Lancet 1996, 347:363-366.

88. Gregoire G, Derderian F, LeLoirer J: Selecting the language of the publications included in a meta-analysis: is there a Tower of Babel bias? J Clin Epidemiol 1995, 48:159-163.

89. Sterne AJC, Bartlett $C$, Jüni $P$, Egger M: Do we need comprehensive literature searches? A study of publication and language bias in metaanalyses of controlled trials. 3rd Symposium on Systematic Reviews: beyond the basics Oxford; 2000.

90. Vogel F, Werner $H$, Exner M, Marx M: Prophylaxis and treatment of respiratory tract infection in ventilated patients by endotracheal administration of aminoglycosides. Dtsch Med Wochenschr 1981, 106:898-903.

91. Rathgeber J, Zielmann S, Panzer C, Burchardi H: Prevention of pneumonia by endotracheal micronebulization of tobramycin. Anesthesiol Intenivmed Notfallmed Schmerzther 1993, 28:23-29.

92. Stoutenbeek CP, Van Saene HKF, Miranda DR, Zandstra DF, Langrehr D: The effect of oropharyngeal decontamination using topical nonabsorbable antibiotics on the incidence of nosocomial respiratory tract infections in multiple trauma patients. J Trauma 1987, 27:357-364.

93. Laggner AN, Tryba M, Georgopoulus A, Lenz K, Grimm G, Graninger W, Schneeweiss B, Druml W: Oropharyngeal decontamination with gentamicin for long-term ventilated patients on stress ulcer prophylaxis with sucralfate? Wien Klin Wochenschr 1994, 106:15-19.

94. Sánchez García M, Cambronero Galache JA, López Diaz J, Cerdá Cerdá E, Rubio Blasco J, Gómez Aguinaga MA, Nùñez Reiz A, Rogero Marín S, Oñoro Cañaveral JJ, Sacristán del Castillo JA: Effectiveness and cost of selective decontamination of the digestive tract in critically ill intubated patients. A randomized, double-blind, placebo-controlled, multicenter trial. Am J Respir Crit Care Med 1998, 158:908-916.

95. de La Cal MA, Cerdá E, García-Hierro P, van Saene HKF, Gómez-Santos D, Negro E, Lorente JA: Survival benefit in critically ill burned patients receiving selective decontamination of the digestive tract: a randomized, placebo-controlled, double-blind trial. Ann Surg 2005, 241:424-430.

96. Genuit T, Bochicchio G, Napolitano LM, McCarter RJ, Roghman MC: Prophylactic chlorhexidine oral rinse decreases ventilator-associated pneumonia in surgical ICU patients. Surg Infect 2001, 2:5-18.

97. Macnaughton PD, Bailey J, Donlin N, Branfield P, Williams A, Rowswell H: A randomised controlled trial assessing the efficacy of oral chlorhexidine in ventilated patients. 17th Annual Congress-Berlin, Germany, 10-13 October 2004

98. Grap MJ, Munro CL, Elswick RK Jr, Sessler CN, Ward KR: Duration of action of a single, early oral application of chlorhexidine on oral microbial flora in mechanically ventilated patients: a pilot study. Heart Lung 2004, 33:83-91.

99. Bopp M, Darby M, Loftin KC, Broscious S: Effects of daily oral care with $0.12 \%$ chlorhexidine gluconate and a standard oral care protocol on the development of nosocomial pneumonia in intubated patients: a pilot study. J Dent Hyg 2006, 80:9.

\section{doi:10.1186/cc10285}

Cite this article as: Pileggi et al:: Prevention of ventilator-associated pneumonia, mortality and all intensive care unit acquired infections by topically applied antimicrobial or antiseptic agents: a meta-analysis of randomized controlled trials in intensive care units. Critical Care 2011 15: R155.

\section{Submit your next manuscript to BioMed Central and take full advantage of:}

- Convenient online submission

- Thorough peer review

- No space constraints or color figure charges

- Immediate publication on acceptance

- Inclusion in PubMed, CAS, Scopus and Google Scholar

- Research which is freely available for redistribution

Submit your manuscript at www.biomedcentral.com/submit
Biomed Central 